
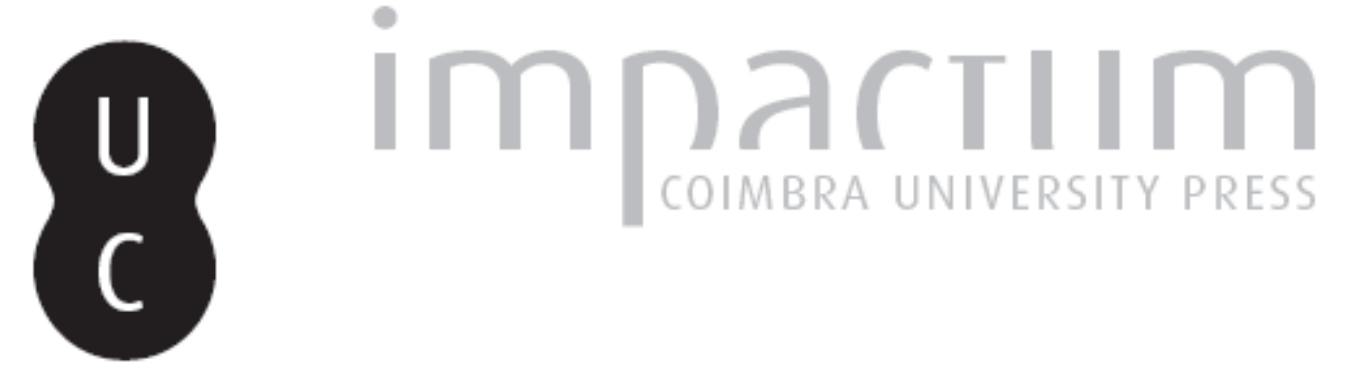

\title{
O papel dos intelectuais na popularização cultural republicana
}

Autor(es): $\quad$ Ribeiro, Lia Sá Paulo

Publicado por: Imprensa da Universidade de Coimbra

URL persistente:

URI:http://hdl.handle.net/10316.2/43721

DOI:

DOI:https://doi.org/10.14195/2183-8925_24_8

Accessed : $\quad$ 26-Apr-2023 15:53:09

A navegação consulta e descarregamento dos títulos inseridos nas Bibliotecas Digitais UC Digitalis, UC Pombalina e UC Impactum, pressupõem a aceitação plena e sem reservas dos Termos e Condições de Uso destas Bibliotecas Digitais, disponíveis em https://digitalis.uc.pt/pt-pt/termos.

Conforme exposto nos referidos Termos e Condições de Uso, o descarregamento de títulos de acesso restrito requer uma licença válida de autorização devendo o utilizador aceder ao(s) documento(s) a partir de um endereço de IP da instituição detentora da supramencionada licença.

Ao utilizador é apenas permitido o descarregamento para uso pessoal, pelo que o emprego do(s) título(s) descarregado(s) para outro fim, designadamente comercial, carece de autorização do respetivo autor ou editor da obra.

Na medida em que todas as obras da UC Digitalis se encontram protegidas pelo Código do Direito de Autor e Direitos Conexos e demais legislação aplicável, toda a cópia, parcial ou total, deste documento, nos casos em que é legalmente admitida, deverá conter ou fazer-se acompanhar por este aviso.

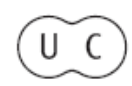



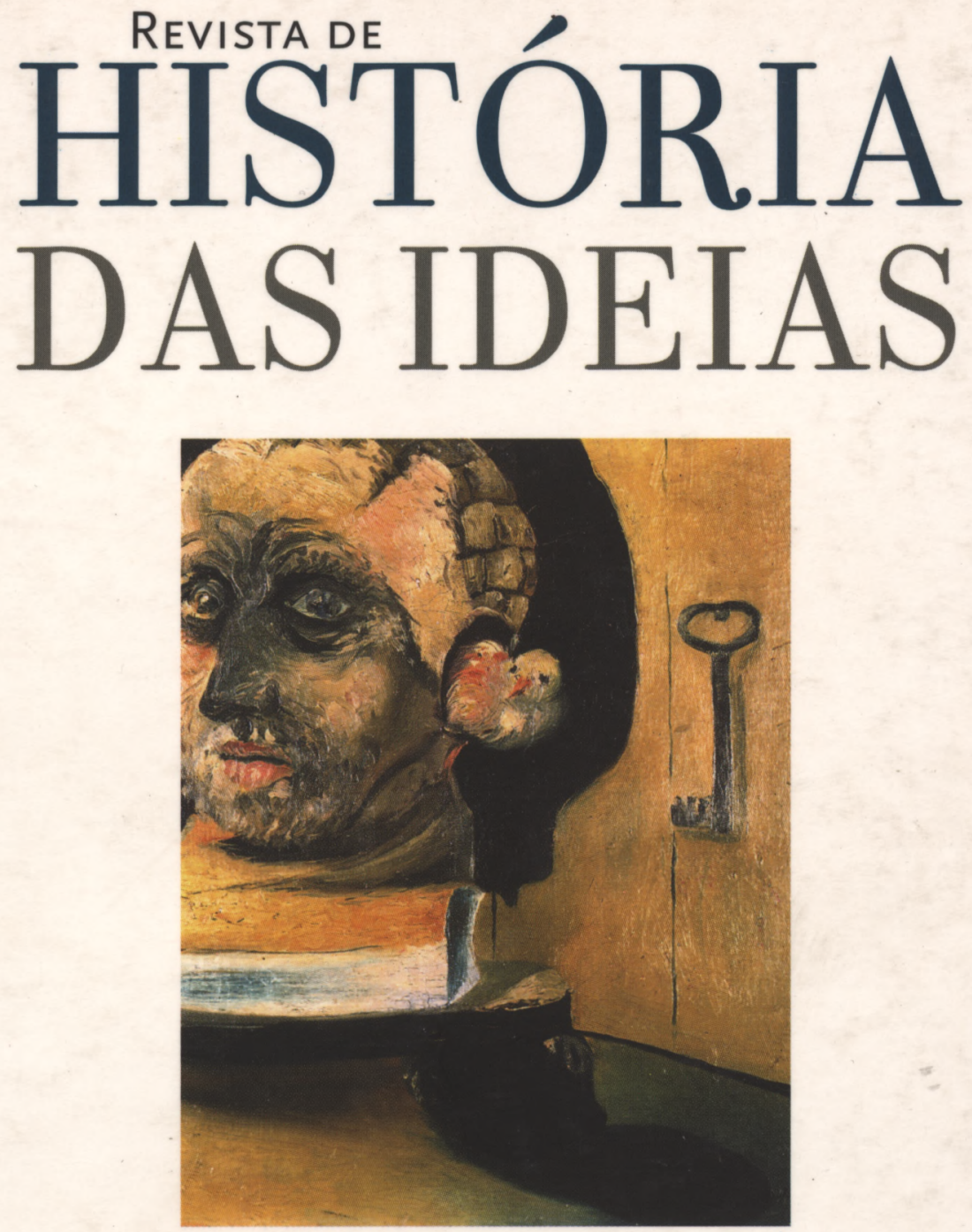

OS INTELECTUAIS E OS PODERES

Volume 24, 2003

INSTITUTO DE HISTÓRIA E TEORIA DAS IDEIAS

Faculdade de Letras da Universidade de Coimbra 


\section{O PAPEL DOS INTELECTUAIS NA POPULARIZAÇÃO CULTURAL REPUBLICANA **}

À memória de meu Pai

"Escuta! É a grande voz das multidões!

São teus irmãos, que se erguem! são canções...

Mas de guerra... e são vozes de rebate!

Ergue-te, pois, soldado do Futuro,

E dos raios de luz o sonho puro,

Sonhador faze espada de combate!"

Antero de Quental, Sonetos

Na sua essência, o republicanismo constituiu uma ideologia, que se pretendia inscrita no sentido do cosmos, da história e da natureza humana. Reivindicava o primado do ideal sobre o real e a sujeição deste àquele, sendo a fundamentação da idealidade ancorada na realidade (apreendida pelas ciências naturais e sociais). Como comprovadamente

* Mestre em História das Ideologias e das Utopias Contemporâneas.

** O presente artigo refunde e alarga os capítulos "Dinamizadores culturais" e "A cultura republicana popularizada" da nossa tese de mestrado intitulada A Popularização da Cultura Republicana (1881-1910), Coimbra, 2003, edição policopiada, sob a orientação do Professor Doutor Fernando Catroga. 
analisou Fernando Catroga, a sua proposta não se circunscrevia à transformação institucional, nem se resumia a uma teoria restritivamente social. A ambição que a condicionava e a animava apontava para a criação de uma nova mundividência, isto é, para uma nova cultura, assente numa renovada espiritualidade, numa refundada memória colectiva, e numa refundamentada axiologia(1).

\section{Da necessidade de popularizar a cultura republicana}

Ao ser totalizante no seu objectivo, o republicanismo procurou um enraizamento popular. É que a pretensão em gerar um novo consenso nacional passava pela criação de um movimento de massas, aglutinador dos diferentes estratos sociais. Acresce ainda que democratizar equivalia a preparar para a cidadania e para a escolha livre e consciente. O sucesso do novo regime, enquanto objectivação política, assentaria na universalidade (pelo menos masculina) do sufrágio, o que pressupunha a universalização da consciência cívica. Ora, a consecução deste desígnio dependia da criação de uma nova opinião pública e da conversão das diversas camadas sociais à ideia antidinástica. Só assim se poderia concretizar a ambicionada revolução cultural emancipadora.

Dito isto, a quem cabia o encargo de hegemonizar ideologicamente a nação segundo a "nova ideia"? Aos intelectuais republicanos, uma minoria que se auto-desafiara para a assinalável tarefa propagadora e catequizadora que então se desenhava. Acreditavam, numa perspectiva evolucionista, cientista e positivista, na inevitabilidade da República, porque esta estaria inscrita, de forma imperativa, na natureza humana e no devir da história (e até do próprio universo). Ante a emergência inelutável da nova era, os intelectuais arvoravam-se em mediadores entre o povo, desconhecedor dos desígnios que o sobredeterminavam enquanto nação, e o sentido do telos da história (nacional e universal). Inscreviam-se, assim, neste perfil da intelligentzia oitocentista, traçado por Pierre Rosanvallon: "les vraies élites ne sont donc ni celles de la fortune, ni celles de la naissance, ni même celles du simple mérite. Elles se

(1) Cf. Fernando Catroga, O Republicanismo em Portugal. Da formação ao 5 de Outubro de 1910, 2 vols., Coimbra, Faculdade de Letras, 1991. 
définissent plutôt par un critère général et la capacité de penser à long terme (alors qu'à l'inverse la majeure partie du peuple est composée $\mathrm{d}^{\prime}$ hommes préoccupés de l'interêt présent et personnel)"(2). Cabia-lhes a função de iluminar o povo e de o fazer sintonizar com a nova idade que irrompia, em que os tempos político, cultural e mental deveriam estar em harmonia. E, segundo Luís da Mata, "esse pobre povo algemado, faminto, ignorante, inconsciente, essa grande multidão de deserdados, de cérebro acanhado, de estômago vazio, merece bem o esforço, o trabalho e a dedicação dos que se orgulham de intelectuais, dos que, possuindo cérebro pensante, vêem o Mal, a Infâmia, a Justiça e contraem nessa visão o dever absoluto de combater toda a miséria e de pregar o Bem!"(3).

Em suma, a vanguarda republicana via no seu papel social uma nova paideia, uma vez que confiava na valorização dos meios pedagógicos para a conversão ideológica e ética. Carreava consigo, num horizonte de perfectibilização contínua, o credo iluminista e optimista no valor da instrução e da educação (cultura) como factores de emancipação humana e de libertação do homem face à sua animalidade; e só os intelectuais poderiam auxiliar a integração dos indivíduos na instância social, dando um novo sentido à colectividade.

Sendo o objecto do nosso estudo o papel dos intelectuais na acção popularizadora republicana, o que entendemos por popularização cultural? Popularizar significa, lato senso, divulgar e vulgarizar junto de um público-alvo específico: as camadas ditas populares. Nada melhor para aliciar os estratos de baixo nível instrutivo do que rentabilizar alguns dos modelos da cultura popular, afeiçoando-os às pretensões propagandísticas democráticas. Tanto mais que permitiam o contacto estreito entre emissor(es) e receptores, solicitando alguns deles a participação activa da assistência, assim investida no simultâneo papel de sujeito e de objecto. Daí não valorizarmos, aqui, a propaganda feita através do livro.

Encontramo-nos, igualmente, perante um fenómeno de consciente $e$ conveniente apropriação de manifestações e vivências culturais não elitistas, mais consentâneas com o que os sociólogos denominam por "baixa cultura", em oposição à "alta cultura" ou "cultura culta". Maurice Agulhon

(2) Pierre Rosanvallon, Le Sacre du Citoyen. Histoire de Suffrage Universel en France, Paris, Éditions Gallimard, 1992, pp. 376-377.

(3) Vanguarda, $\mathrm{n}^{\circ} 1726$ (3673), 25-8-1901, p. 1, col. 1. 
apelidou esta aproximação republicana à cultura tradicional de "folklore démocratique"(4).

A reflexão sobre a aproximação intencional dos dirigentes republicanos - pertencentes maioritariamente à classe burguesa - aos estratos populares coloca-nos a questão do "clássico" antagonismo entre a cultura popular e a cultura de elite. Enquanto aquela emerge como cultura-objecto, esta afirma-se como cultura-sujeito $^{(5)}$; mas ambas se definem pela oposição que estabelecem mutuamente. É certo que o ângulo de abordagem das duas formas culturais é determinado pela "alta cultura". As manifestações culturais do povo, a chamada "pequena cultura", ou "cultura dominada", foram tipificadas, tendo em consideração elementos caracterizadores, como a perenidade, o conservadorismo, a autenticidade reveladora da "alma colectiva ingénua"(6).

Sendo evidente o interesse revelado pelos intelectuais republicanos para com as práticas culturais populares, como explicar a aproximação de uma forma de alta-cultura à cultura-baixa? Esta abordagem deverá ser, na nossa perspectiva, esboçada a partir de dois ângulos complementares.

Por um lado, temos a percepção de que as práticas culturais do proselitismo em análise se inserem nos padrões da cultura burguesa oitocentista, ou seja, na cultura dominante e erudita. Mas, por outro lado, há que considerar o modo particular como o republicanismo concebeu a "cultura baixa". De facto, os republicanos manifestaram algum receio pelo destino das classes populares, nomeadamente do proletariado. Houve pois a necessidade de culturizar os estratos inferiores da população, de acordo com os padrões da "alta cultura", quer através da alfabetização(7),

(4) Maurice Agulhon, Marianne au Pouvoir. L'Imagerie et la Symbolique Républicaines de 1880 à 1914, Paris, Flammarion, s.d., p. 119.

(5) Cf. Boaventura Sousa Santos, Pela mão de Alice. O Social e o Político na Pós-modernidade, Lisboa, Edições Afrontamento, 1994, p. 168.

(6) Maria de Lourdes Lima dos Santos, "Questionamento à volta de três noções (a grande cultura, a cultura popular, a cultura de massas)", Análise Social, vol. XXIV (101-102), $1988\left(2^{\circ}-3^{\circ}\right)$, p. 689.

(7) António Nóvoa cifrou a taxa de analfabetismo total para 1900 em 78,6\%, sendo de $71,6 \%$ para o sexo masculino e de $85 \%$ para o sexo feminino. (A. N., Le Temps des Professeurs, vol. I, Lisboa, I.N.I.C., 1987, p. 351). Já em 1911 a taxa foi calculada em $70,3 \%$, sendo que Lisboa era à data o distrito com a taxa de analfabetismo mais baixa (48,9\%). (Idem, vol. 2, p. 569 e 571). Veja-se ainda Raul Rêgo, História da República, vol. II, Lisboa, Círculo de Leitores, 1986, p. 75. 
quer por via da inculcação de uma cultura geral e profissional, procedimento que se enquadra na explicação dada por Villacorta Baños, ao afirmar que "a acción de los Estados y de las sociedades civiles de la Europa del siglo XIX, en favor de la integración cultural de las clases populares implicaba, al mismo tiempo, su adoctrinamiento en los valores esplícitos o implícitos de una cultura dominante, que se presentaba como la sola cultura digna de tal nombre, es decir, como un modelo cultural de carácter general"(8). Nesta aproximação cultural predominou "una componente interclassista y conciliadora de la cultura, la idea de que esta podía ser el terreno de encuentro de las posturas políticas irreconciliables entre burguesía y proletariado, como de hecho se estaba produciendo entre ciertos estratos de la aristocracia obrera y de la pequeña clase media, encumbrados a esas posiciones gracias a las potencialidades de promoción social de la enseñanza primaria y de la formación profesional"(9). A interferência da burguesia nas produções culturais populares evidencia, também, o reconhecimento da impotência auto-organizadora do povo, o que o tornava dependente da tutela da cultura erudita. Seria uma forma de disciplinar e até de domesticar, mas, simultaneamente, de elevar as elaborações e o nível cultural das classes populares.

Conclui-se, assim, que o movimento republicano estabeleceu um estreitamento cultural junto das camadas populares com o fito de difundir a sua mundovisão, configurada por expressões culturais que, tradicionalmente, reproduziam a espontaneidade e a autonomia do povo. Ainda que preenchidas por uma nova mensagem de índole diferente, as populações poder-se-iam rever nelas e apreender o seu teor, porque formalmente lhes eram familiares. Por isso, esta republicanização das consciências não podia resultar da exclusiva transmissão racional do ideário democrático por parte dos intelectuais em direcção ao público receptor. Os conteúdos ideológicos deviam ser retidos no coração, pela via do sentimento e da afectividade, reforçados pela vivificação de uma nova moral social. Di-lo explicitamente Angelina Vidal, ao alertar os republicanos para que estivessem conscientes de que só depois de se ter feito um filósofo "do último habitante da aldeia de Paio Pires, poderemos implantar a bandeira republicana nesta infeliz nacionalidade, porque se

(8) Francisco Villacorta Baños, Culturas y Mentalidades en el siglo XIX, Madrid, Editorial Sínteses, 1993, p. 175.

(9) Idem, ibidem, p. 177. 
não se fez luz no coração social, ainda antes de ensinarmos a ler ao operário lisbonense, teremos perdido a pátria e a honra e com ela a veneração dos países cultos" ${ }^{\prime(10)}$. Neste horizonte de sociabilidade cívica, nem os dinamizadores seriam os únicos agentes activos, nem o público-alvo se deveria remeter a uma posição de impávida passividade. A eficácia da popularização cultural seria tanto mais efectiva quanto maior fosse $o$ empenho activo de todos os agentes envolvidos. Por conseguinte, comprende-se que procurassem ultrapassar a aç̧ão da escrita (através do livro ou do artigo de imprensa) para realizar esta tarefa. Recorde-se ainda que a intelectualidade democrática, para a consecução da sua missão culturizadora e endoutrinadora, se auto-investiu do múnus de, profeticamente, exercer a catequização do povo e propulsionar a mudança em sintonia com aos valores essenciais da modernidade.

\section{Dinamizadores da popularização cultural republicana}

É no contexto acima descrito que devem ser enquadradas a missão e a identidade dos animadores culturais antidinásticos. Tendo a nossa abordagem incidido no universo da popularização cultural, para procedermos à identificação dos mais relevantes dinamizadores republicanos, contabilizámos a sua participação entre 1880 e 1910 no respeitante aos comícios, conferências e restantes actividades culturais em que estiveram envolvidos. Nestas últimas incluímos: festas cívicas, passeios, excursões, sessões solenes e récitas (teatrais, musicais e/ou literárias). Como se vê, privilegiamos as práticas que, ao invés da leitura (do livro, do artigo escrito), implicavam uma relação mais directa e inter-pessoal entre os emissores e o seu público.

Partindo dessa quantificação, concluímos - à imagem do estabelecido por Fernando Catroga para os dirigentes do Partido Republicano no atinente ao primeiro directório (1883) - a existência de um predomínio de quadros da função pública e de elementos ligados às profissões liberais ${ }^{(11)}$. Do período entre 1880 e 1910 , seleccionámos os 20 protagonistas mais activos na propaganda (conferências, comícios e outras acções

(10) Angelina Vidal, "O que é?", Almanach do Século para 1882, Lisboa, Typographia Nacional, 1881, p. 83 (sublinhado nosso).

(11) Fernando Catroga, ob. cit., vol. I, p. 104. 
culturais). São eles, de acordo com o número de participações e por ordem decrescente: Augusto José Vieira, Agostinho Fortes, Manuel de Arriaga, Magalhães Lima, Bernardino Machado, António José de Almeida, João de Meneses, Sá Pereira, Fernão Botto-Machado, Teófilo Braga, Alexandre Braga, Heliodoro Salgado, Feio Terenas, Gomes da Silva, Brito Camacho, Afonso Costa, Angelina Vidal, Elias Garcia, João Chagas e Consiglieri Pedroso (ver Anexo I).

A exegese dos elementos desta elite permite-nos retirar algumas conclusões. Verifica-se o primado dos intelectuais de profissão (professores, jornalistas, poetas, escritores rondavam os $65 \%$ ), o que corrobora a prevalência da matriz ideológica deste activismo. Mas, se alargarmos a nossa quantificação ao exercício de outras actividades paralelas ao âmbito profissional, vê-se que todos os elementos do escol em apreço se dedicavam ao jornalismo, à escrita ou à poesia, à excepção de Afonso Costa, cuja intervenção como publicista não foi extensa. Por seu turno, neste núcleo avulta a formação na área jurídica $(25 \%)$, militar $(10 \%)$, Curso Superior de Letras (10\%), Escola Politécnica (5\%) e Escola Médico-Cirúrgica (5\%). Mas, no conjunto, frequentaram a Universidade de Coimbra $40 \%$ dos elementos em questão.

Uma análise comparativa entre os dois períodos de maior intensidade propagandística (1880-1891 e 1897-1910) comprova a redução do peso da formação técnica e a crescente importância da educação de base jurídica. Todavia, a par da formação, o que importava era a capacidade oratória. Este facto poderá justificar a notabilização e popularidade tribunícia que os paladinos antimonárquicos adquiriram, principalmente a partir de 1906. As palavras de António José de Almeida, médico e prosélito republicano com maior participação em comícios, espelham o alcance desta capacidade de entusiasmar: "Os oradores, conferentes ou tribunos, espalhados, ao mesmo tempo, por todo o país, farão vibrar a alma nacional pelo amor da mesma ideia. Meia dúzia de homens com vontade e energia tendo a eloquência da alma a secundar a eloquência da palavra darão ao nosso credo um prestígio imparável [...]. Tal ponto perdido na província distante onde a aç̧ão republicana mais frouxa requer um homem de palavra persuasiva, sedutora, que fascine os espíritos com suavidade como certos perfumes que hipnotizam o cérebro sem ele o sentir"(12).

(12) António José de Almeida, "Partido Republicano", in Quarenta Anos de Vida Literária e Política, vol. I, Lisboa, J. Rodrigues \& C ${ }^{a}, 1933$, pp. 80-81. 
No lugar cimeiro da hierarquia dos dinamizadores culturais pontificam figuras como Augusto José Vieira, Agostinho Fortes, Heliodoro Salgado e Fernão Botto-Machado, que reflectem o peso da ala mais radical do Partido Republicano, fortemente conotada com o livre-pensamento, a maçonaria e o socialismo "possibilista". O que também explica o envolvimento nas acções de popularização de homens como José do Vale, Sá Pereira, Pedro Muralha ou Guedes Quinhones, inseridos no movimento socialista e anarquista. Estes elementos vêm ao encontro da opinião de Fernando Catroga, para quem o derrube da monarquia se forjou numa espécie de "frente maçónica, carbonária e republicana"(13), que englobou não só republicanos mas também alguns monárquicos dissidentes $\mathrm{e}$ outros grupos anarquistas e socialistas. De entre todas as problemáticas, a questão religiosa funcionou, claramente, como o cadinho onde os diversos matizes ideológicos (questão política, questão social, questão educativa) se articularam e fundiram ${ }^{(14)}$.

Com base na interpretação dos dados relativos ao empenho desta vanguarda republicana nas diversas actividades culturais promovidas em Lisboa, foi possível verificar quais as personalidades de maior militância (sendo esta inferida a partir do seu grau de participação) envolvidas, ainda que em níveis diferentes, nesta multiplicidade de acções.

No que respeita aos comícios, António José de Almeida (64), João de Menezes (53), Magalhães Lima (53), Alexandre Braga (51), Bernardino Machado (48), Manuel de Arriaga (42) e Afonso Costa (39) afirmaram-se como os principais protagonistas. Se considerarmos o cômputo das acções concernente ao período de 1880 a 1910, depreende-se que os comícios, em concomitância com a actuação parlamentar, foram os palcos privilegiados de celebrização política e pública da "segunda geração" republicana. Excluindo Manuel de Arriaga, Magalhães Lima e Alexandre Braga, que participaram com regularidade em meetings ${ }^{(15)}$ desde finais da década de 70 até à República, a maioria dos "notáveis" oradores

(13) Fernando Catroga, ob. cit., vol. I, p. 135.

(14) Cf. António Ventura, Anarquistas, Republicanos e Socialistas em Portugal. As convergências possiveis (1892-1910), Lisboa, Edições Cosmos, 2000.

(15) Sobre esta expressão, Vasco Pulido Valente esclarece que "os comícios começavam a tornar-se populares em Portugal, sob o seu nome inglês, e os seus promotores e participantes eram conhecidos por 'mitingueiros'" (V. P. V., Glória. Biografia de J. C. Vieira de Castro, Lisboa, Gótica, 2001, p. 140). 
insere-se na geração que só emergiu, politicamente, na primeira década de Novecentos e, mais precisamente, a partir de 1903. Note-se que este núcleo de hábeis retóricos do pós-Ultimato coincidiu, na sua quase totalidade, com o conjunto de elementos que irão constituir o primeiro Governo Provisório após o 5 de Outubro de $1910^{(16)}$.

Todavia, para a economia deste estudo, considerámos, de maior relevo, outros meios de divulgação ideológica, não dirigidos às multidões, mas de matriz inter-pessoal, em que o contacto entre o auditório e o orador é bastante estreito. No domínio das actividades culturais, como festas cívicas, passeios, excursões, sessões solenes e récitas (teatrais, musicais, literárias), e em que não integrámos as conferências, Augusto José Vieira, que interveio em acções de propaganda desde 1885 até 1910, afirmou-se como figura cimeira, com 184 participações. A par da sua actuação na dinâmica de culturização popular organizada pela instituição partidária, envolveu-se em iniciativas da Associação do Registo Civil, de que foi presidente, e da Federação de Livre-Pensamento, de que foi secretário. Seguem-se, como promotores culturais importantes, Magalhães Lima (149), Bernardino Machado (117), Manuel de Arriaga (104), Agostinho Fortes (78), Fernão Botto-Machado (71), Gomes da Silva (71) e Sá Pereira (70). O primeiro e o terceiro revelaram uma notável regularidade entre 1880 a 1910; a vitalidade de Gomes da Silva notabilizou-se na década de 1880; os restantes pertenciam à "segunda geração" republicana.

Constituindo as conferências um importante núcleo das acções de popularização cultural republicana, o seu alcance qualitativo e quantitativo justifica uma abordagem específica. Das 1935 contabilizadas entre 1875 e $1910^{(17)}$, Agostinho Fortes foi responsável por 140, das quais proferiu apenas 8 até 1905. Quer isto dizer que, de 1905 a 1910, fez 132

(16) Para confirmar que o núcleo principal do Governo Provisório republicano se estruturou com base nos notáveis da oratória, saliente-se que António José de Almeida, Bernardino Machado, Afonso Costa e Brito Camacho se inserem nos dez oradores mais participantes em comícios. Por outro lado, importa situar essa actuação no tempo. Assim, António José de Almeida iniciou aparições continuadas em 1905; Bernardino Machado em 1903; Afonso Costa e Brito Camacho, apesar de algumas participações esporádicas entre 1897 e 1904, só a partir deste último ano se empenhou com mais assiduidade na propaganda.

(17) Estas conferências foram contabilizadas a partir da consulta sistemática das seguintes fontes periódicas: O Século (1881-1891); Vanguarda (1900-1909); O Mundo (1900; 1905;1908); A Lucta (1906, 1909-1910). 
palestras, a maioria das quais dedicada à temática histórica. Destacou-se, assim, dos demais conferencistas, mormente de Manuel de Arriaga (79), Augusto José Vieira (77), Teófilo Braga (74), João de Menezes (69) e Heliodoro Salgado (61). E não foi mais longe, porque morreu em 1906, precisamente no ano em que se iniciou a mais intensa fase propagandística e em que grangeou grande popularidade.

No conjunto de comícios, conferências e outros meios de difusão oral, apurámos que, no que respeita à cidade de Lisboa, Manuel de Arriaga e Magalhães Lima foram os intervenientes de maior regularidade ao longo do período em questão. No atinente ao quantitativo de acções participadas sobressaem Augusto José Vieira, Agostinho Fortes, João de Menezes e Bernardino Machado, personalidades que corporizavam a "oligarquia" que alimentava a vida partidária.

No que respeita às mulheres, destacou-se Angelina Vidal que, navegando nas águas do "social-republicanismo", proferiu 34 conferências e participou em múltiplas actividades em centros democráticos ou operários ${ }^{(18)}$. A sua acção situou-se entre a década de 80 do século XIX e a primeira década de Novecentos. Nesta última conjuntura, afirmaram-se no movimento republicano mulheres como Maria Veleda (qualificada por um autor catalão como "una dona de mereixement conferenciant, lliure-pensadora" $\left.{ }^{\prime(19)}\right)$, Ana de Castro Osório e Maria Clara Correia Alves. O seu envolvimento na propaganda antidinástica (e feminista), a par do livro e da imprensa, privilegiou as conferências e as actividades de índole cultural, nomeadamente junto do operariado (Maria Veleda) e do público infantil (Ana de Castro Osório) e feminino (ver Anexo II).

Em termos geográficos, a análise centrou-se, sobretudo, em Lisboa. É que, se o activismo político-cultural chegou a outras localidades, foi na capital que o republicanismo alcançou a sua mais forte militância e a sua mais ampla e aguerrida base de apoio.

(18) Ribera y Rovira apodou a escritora de "eremita en la sociologia i en la poesia i altres, prenen un relleu magnific i són prestigi nobilissim de la literatura patria", Ribera y Rovira, Portugal Literari, vol. I, Barcelona, Libreria "L'Avenq", 1912, p. 113.

(19) Idem, ibidem, p. 114. 


\section{Evolução da aç̧ão cultural}

Ao longo do lapso temporal por nós estudado, as fontes registaram dois períodos distintos de dinamização cultural, directa ou indirectamente republicanizante. Grosso modo, o primeiro situou-se entre 1881 e 1891 e, o segundo, entre 1896 e 1910:

\section{Evolução da participação em conferências, comícios e actividades culturais (1881-1910)}

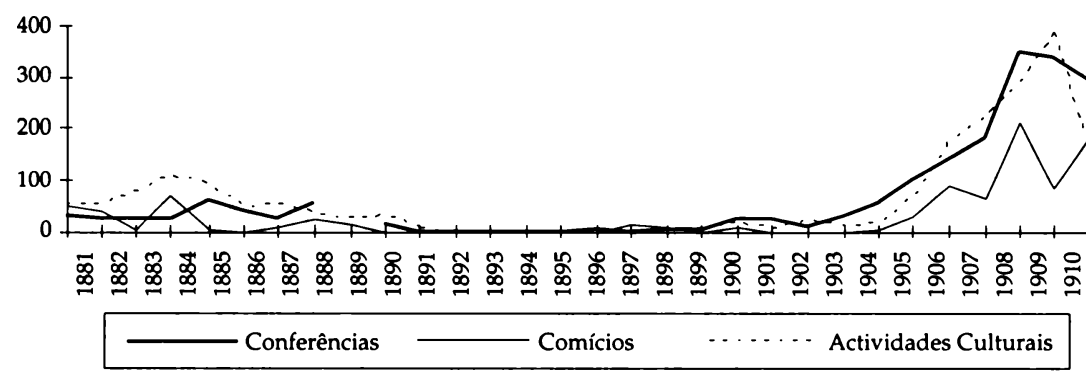

Na génese da fase inicial, estiveram as Comemorações Camonianas de 1880, que corresponderam ao primeiro ensaio de unificação republicana. Sob o signo dessa união, nasceram múltiplas agremiações, sintoma do propósito em conglomerar esforços, pois os clubes eram encarados como instrumentos nucleares para desenvolver o labor propagandístico e doutrinário.

Na primeira fase definida (1880-1890), o cume deu-se entre 1884-1885, coincidindo com os anos em que, em resultado da estruturação partidária de 1883, o clubismo republicano atingiu o seu auge. Em 1885, contabilizámos 29 centros em Lisboa e 22 na província. Mas, em 1887, contámos menos 5 centros na capital e menos 2 no resto do país. Este decréscimo - que implicou, logicamente, a diminuição de acções culturais - revela alguma instabilidade nas hostes republicanas. A tentativa de aliança com a ala monárquica da "esquerda-dinástica", por um lado, e a emergência das forças remanescentes do federalismo, por outro, estiveram na base da contestação aos órgãos centrais do partido e do dissídio de elementos mais radicais. Desde então, a propaganda foi esmorecendo até 1890, ano em que o Ultimato impulsionou uma acirrada contestação anti-britânica e antimonárquica. Nas vésperas 
do 31 de Janeiro de 1890, o movimento esboçava a sua reorganização através da discussão e aprovação, no congresso de 5 a 7 de Janeiro, do primeiro programa oficial do Partido, em preparação desde 1887. Este esforço seria profundamente afectado pela intentona gorada no Porto, e pela consequente reacção monárquica, que culminou no decreto de Lopo Vaz (20 de Fevereiro de 1891), em que os clubes antidinásticos são apelidados de "criminosos elementos de perturbação da ordem pública"(20). E, dois dias depois, foram proibidos e encerrados os centros republicanos constantes no quadro seguinte:

Clubes Republicanos fechados por ordem do governo monárquico ${ }^{(21)}$

\begin{tabular}{|l|l|l|}
\hline \multicolumn{1}{|c|}{ Clube } & \multicolumn{1}{c|}{ Presidente } & \multicolumn{1}{c|}{ Sede } \\
\hline Associação Escolar Eleitoral Vieira da Silva & Augusto de Figueiredo & Largo Santo Estevão, 9, $1^{\circ}$ \\
\hline Clube Escolar Artístico & José Ferreira da Silva Neves & Rua da Inveja, 41 \\
\hline Centro Eleitoral da Freg. dos Anjose deS. Jorge & João Gonçalves & Rua dos Anjos, 162 \\
\hline Centro Fraternidade Republicana & Magalhães Lima & Páteo de Salema, 4, $1^{\circ}$ \\
\hline Clube Henriques Nogueira & António Cardoso de Oliveira & Rua dos Fanqueiros, 286 \\
\hline Clube Victor Hugo & Casimiro Rodrigues Valente & Rua de S. Paulo, 216 \\
\hline Centro Eleitoral Democrático de Lisboa & Elias Garcia & Rua dos Mouros, 40, $1^{\circ}$ \\
\hline Associação Escolar Eleitoral Febo Moniz & Eduardo José Gaspar & Rua de Vicente Borja, 86, $1^{\circ}$ \\
\hline Associação Escolar Fernandes Tomás & José da C. Castelo Branco Saraiva & Rua de D. Carlos I, 61, $1^{\circ}$ \\
\hline Centro Republicano Federal & José Maria de Sousa & Rua de S. Bento, 393, $1^{\circ}$ \\
\hline Escola Infantil para os Filhos do Povo & Teófilo Braga & Rua de S. Bento, 393, $1^{\circ}$ \\
\hline Clube Razão e Justiça & Magalhães Lima & Rua do Livramento, 88, $1^{\circ}$ \\
\hline Clube Republicano de Cacilhas & & Cacilhas \\
\hline
\end{tabular}

Com aqueles actos legislativos, associados a outros éditos repressivos da liberdade de imprensa - decretos de 29 de Março de 1890 e a famosa "lei dos anarquistas" de 13 de Fevereiro de $1896^{(22)}$ - e atentatórios da liberdade de reunião (decreto de 6 de Abril de 1890), a Monarquia

(20) Diário do Governo, $\mathrm{n}^{\circ} 40,21-2-1891$, p. 373, col. 1.

(21) Lista publicada no jornal O Século, n 3252, 24-2-1891, p. 1, col. 2.

(22) Cf. José Tengarrinha, História da Imprensa Periódica em Portugal, $2^{\mathrm{a}}$ ed., Lisboa, Editorial Caminho, 1989, p. 251 ss. 
enfraquecia os clubes e as suas manifestações culturais quase se apagaram durante a derradeira década de Oitocentos. As sequelas dos decretos em causa foram assaz profundas e duradouras. Entre os anos de $1891 \mathrm{e}$ 1897, consideramos que o associativismo e o dinamismo cultural republicano caíram no que denominamos por "fase do silêncio"(23). Raros são os núcleos democráticos noticiados, o que indicia a desagregação e a tibieza da vida associativa. No entanto, a primacial fonte de informação - a imprensa - esteve também ela condicionada pelo espartilho da censura, de modo que, mesmo que existissem algumas actividades, dificilmente seriam noticiadas.

As iniciativas culturais só voltariam a alcançar maior relevo depois de 1900. A sua quase inexistência, dois anos mais tarde, faz eco do momento de volubilidade partidária, que culmina na substituição do Directório do Partido por três Juntas Directivas, criadas justamente para reanimar a militância de base. Em virtude da acção das Juntas, depois de 1902, a dinâmica cultural entrou em fase decisiva de intensificação. Mas o grande surto activista de todo o percurso de propaganda teve lugar entre 1906 e 1908. Em resposta ao franquismo, o movimento republicano radicalizou-se e entrou numa fase de notável expansão. Os clubes sucederam-se com grande celeridade e disseminação geográfica, complexificando-se organicamente. A sua gramática de propaganda diversificou-se e os vultos do republicanismo granjearam uma forte popularidade no parlamento, nos comícios, na imprensa e em inúmeras iniciativas de doutrinação.

\section{A cultura republicana popularizada: as grandes questões}

Tipificando o conteúdo da propaganda, poderemos apresentar as seguintes questões nela mais relevantes: questão do regime, questão religiosa, questão social, problema educativo, feminismo, história, ciência. Mas, como é lógico, os temas estavam ligados e exigiam-se reciprocamente. Pelo que a sua selecção é discutível, embora assente na relevação do seu teor dominante, indicado pelo título das diversas iniciativas culturais, ou pelos extractos e reportagens inseridos nos jornais.

(23) António Ventura apodou este período de "travessia no deserto", em que, apesar da emergência de novos dirigentes, novas propostas e novas tácticas, foram notórias as divergências no seio do Partido. Cf. A. V., ob. cit., p. 11. 


\subsection{A questão do regime}

No período que decorreu entre 1880 e 1910, o combate explícito à monarquia surge como mote de análise - em conferências, ou em discursos proferidos em iniciativas culturais-em dois momentos distintos: na década de 80 , e, principalmente, no derradeiro lustro do monarquismo constitucional. $\mathrm{E}$, quanto às primeiras, contabilizou-se um total de 616 $(36,5 \%)$, directa ou indirectamente dedicadas à chamada questão do regime.

Evolução do $n^{\circ}$ de conferências dedicadas à Questão do Regime (1880-1910)

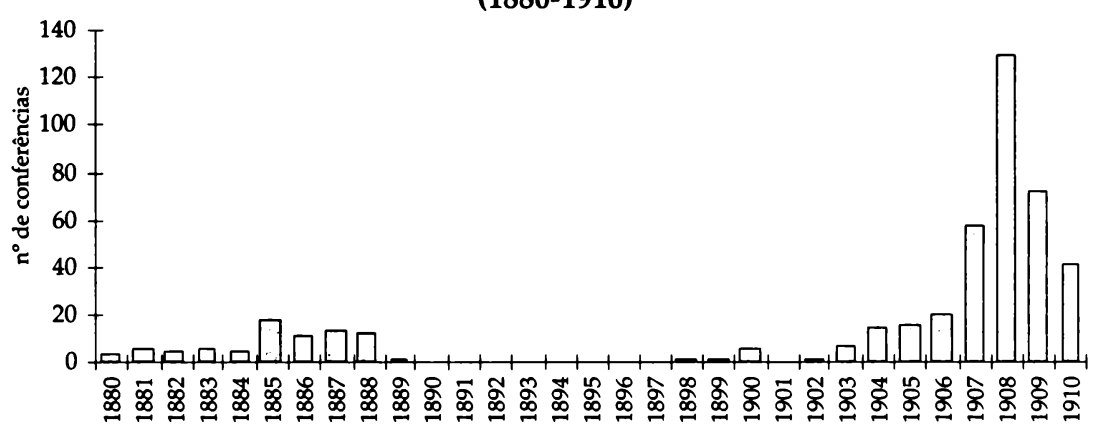

A partir de 1907, face ao autoritarismo franquista, enfatizou-se a luta directa contra a Monarquia, culpabilizando-se o rei e a instituição dinástica pela decadência nacional, agravada pela ditadura. Note-se, ainda, que o ano de 1908 corresponde ao cume da contestação da dinastia de Bragança e do regime, facto a que não terá sido estranha a eleição da vereação republicana para a Câmara Municipal de Lisboa e o regicídio de D. Carlos e de D. Luís Filipe.

\subsection{A questão religiosa}

Um dos sintomas caracterizadores do fundo cultural do republicanismo encontra-se no facto de a questão religiosa ter sido uma das temáticas preponderantes da sua doutrinação, como atestam as $428(25 \%)$ conferências que lhe foram dedicadas. 
Recorde-se que, no Portugal de finais de Oitocentos, o republicanismo, conjuntamente com o socialismo e o livre-pensamento, se situou na vanguarda da contestação à instituição clerical e religiosa. Não foi, por isso, uma problemática exclusiva de um movimento, mas uma plataforma de entendimento com outras linhas de pensamento, próximas ou distantes, que contestavam a ordem estabelecida. Com efeito, do núcleo de fontes compulsadas, podemos verificar que a campanha laicizadora congregou adeptos da facção socialista, livre-pensadora e anarquista com o movimento republicano. Figuras como Teófilo Braga, Heliodoro Salgado, Augusto José Vieira, José do Vale, Guedes Quinhones, Alfredo Ladeira, Macedo Bragança, Magalhães Lima, Maria Veleda, Sá Pereira, entre outros, pontificaram em conferências e actividades anticlericais, quer em círios civis, quer em centros socialistas, quer em grémios operários.

Evolução do $n^{\circ}$ de conferências dedicadas à Questão Religiosa

(1880-1910)

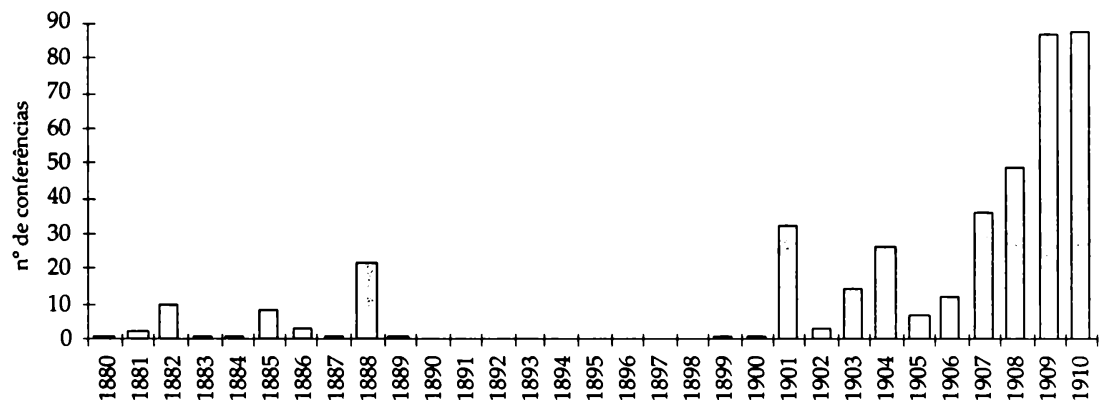

Como consta do gráfico apresentado, no ano de 1881 acentuou-se a campanha anticlerical, em consequência dos esforços do movimento republicano e de anticlericais liberais. A contestação reavivou o velho anticongreganismo liberal, em virtude da penetração ilegal de ordens religiosas recém-expulsas de França e da Bélgica. Idênticos pretextos estão na base do surto de registadas em 1888, ano em que, por exemplo, são conhecidas várias manifestações contra a tentativa de reentrada das Irmãs da Caridade ${ }^{(24)}$.

(24) Algumas dessas manifestações tiveram lugar em Aveiro, como nos relata Homem Cristo, Notas da minha Vida e do meu Tempo, vol. IV, Lisboa, Editora Guimarães e Ca, s.d., pp. 15-16. 
No ano de 1901, a campanha conheceu outra fase de animação, desencadeada, em larga medida, não apenas pelo caso Calmon, mas também pelo decreto de 18 de Abril, promulgado por Hintze Ribeiro, que dava cobertura à entrada e permanência das ordens religiosas em Portugal ${ }^{(25)}$.

O robustecimento da militância de matriz laicista, protagonizada, sobretudo, por núcleos anticlericais, operários e de livre-pensamento, em coalizão com organismos republicanos, atingiu o seu auge imediatamente antes do 5 de Outubro de 1910, conjuntura em que a luta atingiu o zénite ${ }^{(26)}$. Datam deste período a organização do Congresso Nacional do Livre-Pensamento (1908), a realização da "Semana Laica" pela Federação Nacional do Livre-Pensamento (1908) ${ }^{(27)}$ e a promoção de numerosos comícios e manifestações antijesuíticos, como a de 1 de Agosto de 1909, organizada pela Liga Liberal, que reuniu mais de 100 mil pessoas ${ }^{(28)}$. Todas estas movimentações são consentâneas com a crescente relevância que a problemática religiosa adquiria na dinâmica cultural (e política) antidinástica.

Para agudizar a situação, esta também foi a fase em que a questão religiosa - o mesmo é dizer a campanha pela laicização - surgiu mais intimamente enlaçada, não só com a questão do regime, mas também com a questão social, dando-se expressão à promessa de que, para a emancipação humana era necessário uma revolução em que, à prioridade do político, deveria seguir-se uma revolução cultural e social.

\subsection{A questão social}

Como consequência da industrialização e da substituição da sociedade de ordens pela sociedade de classes, o século XIX assistiu à emergência de uma nova questão social: a que tinha por base o problema do operariado. Sabemos que os trabalhadores assalariados formavam uma

(25) Cf. Vanguarda, no 1843 (3796), 23-12-1901, p. 2, col. 4 e no 1856 (3809), 6-1-1902 , p. 1, col. 5 .

(26) Cf. Manuel Braga da Cruz, "Os católicos e a política nos finais do século XIX", in O Século XIX em Portugal, Lisboa, Editorial Presença, 1979, pp. 289-300.

(27) Cf. Fernando Catroga, "O livre-pensamento contra a Igreja", Revista de História das Ideias, vol. 22, 2001, pp. 338-354.

${ }^{(28)}$ Cf. Vanguarda, n ${ }^{\circ} 4511$ (7382), 1-8-1909, p. 1, cols. 1-6 e n 5412 (7383), 2-8-1909 , p. 1, cols. 1-6. 
percentagem diminuta da população portuguesa, e mais reduzidos eram os que integravam o sector fabril. Concentravam-se nas grandes urbes, sobretudo em Lisboa, tal como o grosso da militância e inteligência democrática. Não se estranha, por isso, a ênfase lograda pela questão operária na actividade popularizadora e na ideologia republicana. Da globalidade de conferências compulsadas, 90 (5\%) abordaram incisivamente a problemática social. Esta, porém, não foi considerada de uma forma contínua, ao longo dos últimos trinta anos da Monarquia. Mas, se se atentar no gráfico, detecta-se a existência de três conjunturas em que ela foi focada com alguma insistência.

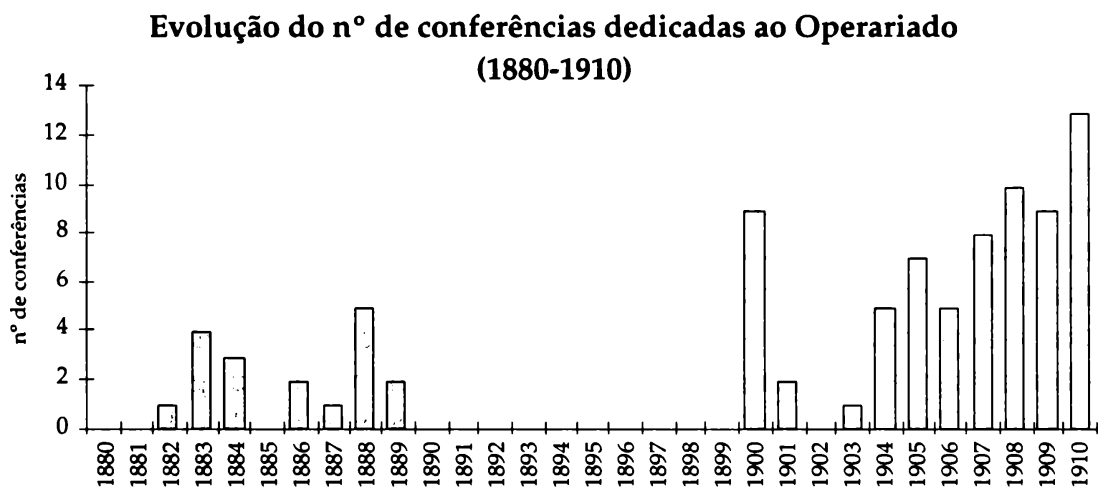

A primeira fase situou-se na década de 1880 . O ano de 1900 conheceu um novo surto. Para tal, terá contribuído a consagração programática da questão operária assumida pelo Grupo Republicano de Estudos Sociais (1896) e a aproximação entre republicanos e alguns núcleos socialistas dissidentes de orientação "marxista" do Partido Socialista liderado por Azedo Gneco. Da união de esforços resultou a criação do Grémio Republicano Concentração Democrática, clube misto de prosélitos da democracia e do socialismo. Neste contexto, Brito Camacho proferiu uma palestra no Centro Socialista Ocidental sobre "Concentração Democrática". O conferente apelou à participação política dos socialistas e "defendeu que a República é o regime político que pretende tornar mais fáceis as transformações sociais. Nela cabe o socialismo e as aspirações socialistas" ${ }^{\prime 29)}$.

(29) Vanguarda, n 1447 (3392), 14-11-1900, p. 1, col. 5. 
Anteriormente, já socialistas e republicanos haviam colaborado eleitoralmente no Porto, em 1899, tendo originado a Concentração Republicano-Socialista ${ }^{(30)}$.

Parece-nos, no entanto, que o estreitamento de relações entre republicanos e socialistas, por iniciativa dos primeiros, deverá ser enquadrado num horizonte mais lato. A publicação, em 1891, da Encíclica Rerum Novarum, pelo papa Leão XIII reforçou a doutrinação social da Igreja e, com ela, a tentativa para integrar algumas reivindicações proletárias dentro do âmbito institucional e doutrinário do catolicismo. Note-se que, logo em 1895, o Congresso Católico Internacional de Lisboa inseriu, na sua ordem de trabalhos, a questão operária e a doutrina da Igreja $^{(31)}$. Ante a posição papal, o movimento republicano combateu em duas frentes: por um lado, actuou junto do operariado, de modo a arredá-lo do socialismo revolucionário; por outro lado, procurou cativá-lo face à dinâmica de influência accionada pela Igreja, mediante a criação de organismos católicos operários.

O recrudescimento da actividade propagandística antimonárquica $e$ anticlerical nos derradeiros anos da Monarquia implicou um novo assomo propagandístico junto das classes laboriosas. Foi neste período que o republicanismo contou com o apoio do trabalho, radicado em Lisboa. Para atrair uma população inculta, utilizou uma linguagem cada vez mais "socializante", recheada de expressões retiradas do discurso socialista, mas eivadas de um sentido pacifista e solidarista. Pretendeu dar resposta, igualmente, a alguns dos problemas mais prementes do operariado, ao propugnar: pela fixação do horário de trabalho semanal em 8 horas ${ }^{(32)}$, pela "supressão dos impostos de consumo, substituindo-os por impostos progressivos, segundo os rendimentos; pelo direito à greve; pela protecção no trabalho e em acidentes de trabalho ou doença e pelo direito à liberdade de associação"(33). Além disso, os dirigentes

(30) Cf. António Ventura, ob. cit., p. 115 ss.

(31) Cf. J. Pinharanda Gomes, Os Congressos Católicos em Portugal, Lisboa, Acção Católica Portuguesa, 1984, pp. 32-33.

(32) Reivindicado por Magalhães Lima em sessão solene ocorrida no Centro Republicano Bernardino Machado, a 1 de Maio de 1908. Cf. Vanguarda, $\mathbf{n}^{\circ} 4059$ (6929), 2-5-1908, p. 1, col. 2.

(33) Cf. Bernardino Machado, Pela República. 1906-1908, Lisboa, Edição do Autor, 1908, p. 253. Sobre o direito à greve, Fernão Botto-Machado descrevia-o como "exemplo de solidariedade de uma classe reagindo contra a opressão e a 
republicanos procuraram mostrar que a melhoria da situação económica e política do povo dependia, prioritariamente, do fim do regime monárquico e da emergência da República, que proporcionaria a laicização do Estado, a universalização (masculina) do sufrágio bem como a derrocada dos grandes poderes capitalistas.

Institucionalmente, as relações entre muitos organismos democráticos e algumas associações de classe espelhavam uma certa contaminação republicana por parte destes grémios e reflectiam a sua posição face à problemática do operariado. Era nestes espaços onde melhor se materializava a permeabilização de dinâmicas entre republicanos e socialistas. Dirigentes antimonárquicos na oposição e, sobretudo, na dissidência, integravam-se em sessões solenes, ou proferiam conferências em agremiações operárias ${ }^{(34)}$, enquanto núcleos ligados ao associativismo de classe (anti-Gneco) reuniam e organizavam a sua estrutura associativa nos clubes republicanos ${ }^{(35)}$. Alguns republicanos chegaram mesmo a associar-se à comemoração do $1^{\circ}$ de Maio ${ }^{(36)}$. Esta interacção implicava, por norma, a focalização de temas específicos e aglutinadores das duas correntes, tendo como pano de fundo a reivindicação da melhoria das condições de vida e de trabalho do operariado, a temática anticlerical, a solução cooperativista, etc.

\subsection{O feminismo}

Uma outra expressão do projecto emancipador que animava o republicanismo (pelo menos alguns dos seus intelectuais) encontra-se no relevo que foi dado à questão do feminismo. Sem o radicalismo alcançado

exploração do capital e exigindo ou o aumento do salário, ou a diminuição das horas de trabalho. Só isto" (F. Botto-Machado, Crenças e Revoltas, Lisboa, Typographia Bayard, 1908, p. 26).

(34) Por exemplo, a participação de "notáveis" republicanos em actividades promovidas pela Caixa Económica Operária ou pela Voz do Operário. (Cf. Vanguarda, $\mathrm{n}^{\circ} 3890$ (6761), 14-10-1909, p. 3, col. 2).

(35) Entre 1885 e 1886, clubes republicanos e alguns grémios operários concertaram esforços a favor do descanso semanal e, em 1890, reivindicaram "a regulamentação das horas de trabalho e a organização de uma séria inspecção às condições higiénicas nas oficinas" (O Século, n² 2842, 7-1-1890, p. 1, col. 6).

(36) Foi o caso do $1^{\circ}$ de Maio de 1908 , que contou com a presença de Bernardino Machado e Andrade Neves. Cf. Illustração Portugueza, nº 116, 11-5-1908, p. 116. 
em outros países (Inglaterra, Estados Unidos, França), a verdade é que certas reivindicações do movimento - mormente ao nível dos direitos civis e da luta pela educação da mulher - surgiram, em Portugal, intimamente ligadas à luta anticlerical e antidinástica dos primórdios de Novecentos.

Com efeito, ao longo do período que temos vindo a estudar, a acção de alguns elementos republicanos - em que destacamos Fernão BottoMachado, António José de Almeida, Magalhães Lima - em prol de alguns direitos das mulheres fez deste feminismo moderado um dos temas recorrentemente vulgarizados. Por sua vez, nos finais de Oitocentos, começou a emergir um pequeno núcleo de feministas (atrás referenciado), ligado à maçonaria, e que revelará uma influente capacidade propagandística e organizativa.

Evolução do $n^{\circ}$ de conferências dedicadas ao Feminismo

(1880-1910)

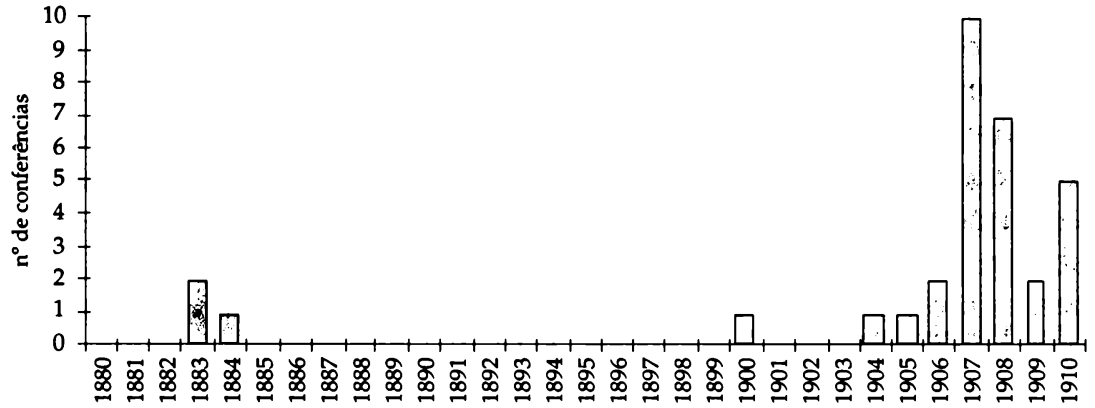

No período estudado, registámos 32 conferências $(1,9 \%)$ explicitamente dedicadas à questão feminina. Como atesta o gráfico, registou-se um surto de acções sobre esta temática a partir de 1907. Parece-nos que a este facto não terá sido alheia a criação, ainda que fugaz, do Grupo Português de Estudos Feministas, primeira organização que visava a dignificação do estatuto da mulher ${ }^{(37)}$. A campanha feminista conheceu novo recrudescimento a partir de finais 1909, no seguimento da fundação da Liga Republicana das Mulheres Portuguesas, associação que se

(37) Na sequência da fundação deste grupo foi organizado um ciclo de conferências intitulado "série dedicada às senhoras", que decorreu na Sociedade Promotora de Educação Popular. Cf. Vanguarda, no 3734 (6593), 1-4-1907, p. 2, col. 5. 
prpunha "orientar, educar e instruir, nos princípios democráticos a mulher portuguesa, como mãe de família, esposa, filha, educadora, tornando-a um indivíduo consciente [...]; fazer propaganda cívica, inspirando-se no ideal republicano e democrático"(38).

De facto, como objectivo fundacional, este grupo de pressão pretendia "promover imediatamente [...] a discussão, no parlamento, do projecto sobre a questão do divórcio"(39). Por conseguinte, não surpreende que o primeiro ciclo de conferências, organizado pela Liga, tenha sido dedicado à referida questão, e tenha decorrido em agremiações antidinásticas ${ }^{(40)}$; e que, logo em Novembro de 1910, um grupo de representantes seus se tenha dirigido ao Governo Provisório, solicitando a publicação da lei do divórcio e a revisão do Código Civil, em todos os aspectos que reduzissem as capacidades jurídicas e civis da mulher ${ }^{(41)}$.

Importa, neste momento da exposição, equacionar o modo (ou os modos) como a temática feminina foi abordada no discurso republicano e na sua dinâmica popularizadora.

Em linhas gerais entendiam o feminismo como "o sistema que pretende integrar a mulher em todos os direitos políticos e civis de que o homem goza, quando na sua plena posse jurídica" (42). Por esta definição finissecular perpassa uma das vertentes da emancipação da mulher: a obtenção da igualdade do ponto de vista jurídico em relação ao homem, "para que o marido não seja o tirano ou o déspota, o detentor, o adminis-

${ }^{(38)}$ Cf. Ibidem, $\mathrm{n}^{\circ} 4142$ (7013), 25-7-1908, p. 2, col. 6. A Liga foi constituída em Fevereiro de 1909, (cf. Ibidem, nº 4358 (7229), 28-2-1909, p. 2, col. 1). Para além da função propagandística, visava também "fundar cursos livres de higiene, economia doméstica, agricultura, jardinagem, corte e pequenas indústrias caseiras para preparar a mulher para professora das futuras escolas domésticas". (Ibidem, $\mathrm{n}^{\circ} 4361$ (7232), 3-3-1909, p. 1, col. 2).

(39) A Mulher e a Criança, $\mathrm{n}^{\circ} 1$, Abril 1909, p. 11.

(40) Em Abril de 1909 foram realizadas duas conferências, sobre a questão do divórcio, no Centro Republicano António José de Almeida e no salão da "Ilustração" do Século. Cf. Ibidem, n 3, Maio de 1909, p. 2.

${ }^{(41)}$ Cf. Fernando Catroga, "A Laicização do Casamento e o Feminismo Republicano", A Mulher na Sociedade Portuguesa. Actas do Colóquio, Coimbra, Coimbra Editora, 1986, p. 143 e Geneviève Fraisse e Michelle Perrot (dir.), História das Mulheres, vol. 4, O Século XIX, Lisboa, Edições Afrontamento, 1991, pp. 277-295.

(42) Maria Gonçalves de Freitas, "Feminismo", A Mulher e a Criança, $\mathrm{n}^{\circ} 6$, Setembro 1909, p. 1, col. 1. 
trador e o livre dissipador dos próprios bens da mulher"(43). Mas, as suas reivindicações eram mais amplas e advogavam "que o casamento [fosse] a associação pelo amor de dois seres conscientes, livres e iguais. Uma aliança de almas e de espíritos, e não um jogo de conveniências ou de interesses, estúpido e brutal como é actualmente; que a lei moral, civil, política e económica seja a mesma para os dois sexos; que se termine com a limitação à capacidade da mulher e a mulher possa exercer profissões liberais, e que o seu trabalho seja retribuído como o do homem, para que da sua pobreza possa fazer um escudo defensor da sua honra"(44).

Podemos resumir esta perspectiva do feminismo em três questões basilares: primeiro, a defesa da igualdade de direitos civis (mais prioritária do que a igualdade de direitos políticos); segundo, a apologia da igualdade e protecção no trabalho e a liberdade de exercer certas profissões; e, terceiro, a reclamação do livre acesso ao ensino e da alfabetização feminina(45).

No atinente à questão dos direitos civis, a reivindicação principal prendia-se com o pleno usufruto dos seus bens pela mulher, assim como a equiparação, no domínio jurídico, aos direitos do homem ${ }^{(46)}$. Porém, a propaganda democrática enfatizou, sobretudo, a emancipação feminina no trabalho e pela instrução. Frequentemente, invocavam-se as mais recentes descobertas científicas no sentido de sublinhar o equilibrio das capacidades intelectuais entre homens e mulheres, podendo estas "distinguir-se pela ciência, pela indústria, pela arte, pelo comércio, pela pedagogia, ou ficarem tão somente donas de casa, mas fazendo do seu lar a primeira e mais nobre escola para os filhos" ${ }^{\prime(47)}$. Por isso, elas deviam aceder a empregos concordantes com a sua natureza, entre os quais as

(43) Fernão Botto-Machado, Crenças e Revoltas, já cit., p. 128.

(44) Idem, ibidem.

(45) Sousa Viterbo sistematizou estas questões em alguns artigos compilados na obra Cem artigos, insertos no Diario de Noticias de Lisboa e pela empresa deste jornal publicados em homenagem ao seu extinto colaborador, Lisboa, Tipographia Universal, 1912, pp. 87-89; 93-95; 95-97; 102-104; 104-107; 109-111; 111-113.

(46) Sobre a crítica feminina ao Código Civil veja-se Fernando Catroga, A Militância Laica e a Descristianização da Morte em Portugal 1865-1911, Coimbra, Dissertação de Doutoramento policopiada, 1988, vol. I, pp. 351-354.

(47) Cf. Ana de Castro Osório, Às Mulheres Portuguesas, Lisboa, Livraria Editora Viúva Tavares Cardoso, 1905, p. 18. 
profissões liberais ${ }^{(48)}$. Era esta a posição de Fernão Botto-Machado ${ }^{(49)}$, para quem "a mulher é uma força social, fisiologicamente, intelectualmente, ante os códigos e leis, ante a moral e a política [...]. A mulher deve [...] concorrer a empregos, a toda a espécie de trabalho compatível com o seu ser físico e psicologia, para do trabalho poder fazer escudo da sua honra"(50).

Ora, a melhor tradução deste ideal residiu no exemplo vivo de algumas prosélitas do feminismo. Personalidades como Angelina Vidal, Maria Veleda, Ana de Castro Osório, Adelaide Cabete e Maria Clara Correia Alves ${ }^{(51)}$ corporizaram o ideal de autonomia e de afirmação cultural e cívica feminina. Por outro lado, procuraram sublinhar a eficácia da instrução como móbil da emancipação. E, para aumentarem os seus meios de luta, chegaram mesmo a incorporar correntes de vanguarda, como o livre-pensamento ${ }^{(52)}$ ou a instituição maçónica ${ }^{(53)}$.

Um outro ângulo de abordagem da relação entre a mulher e o mundo laboral consistiu na denúncia da precariedade do trabalho feminino. Para Angelina Vidal, “a mulher operária, mercê das deficientíssimas condições de trabalho e da extrema pobreza em que vive não pode criar os filhos de modo a fazer deles os cidadãos de que o país necessita para se assumir como nação civilizada"(54). Por esta razão, a escritora defendeu

(48) Entre os defensores desta ideia salientou-se Magalhães Lima. Cf. M. L., A Obra Internacional, já cit., pp. 38-39.

(49) Fernão Botto-Machado foi o republicano que mais conferências [4] proferiu sobre a questão do feminismo.

(50) Vanguarda, n 3759 (6630), 6-5-1907, p. 2, col. 4.

(51) A primeira proferiu 4 conferências sobre a temática do feminismo; a segunda, 10; a terceira e a quinta, realizaram 2 conferências cada.

(52) Exemplo vivo da adesão ao livre-pensamento foi Maria Veleda, que explicou a adesão a esses ideais num conjunto de artigos intitulados "Porque me fiz livre-pensadora?", publicados no jornal Vanguarda, n 4344 (7215), 13-2-1909, p. 1, cols. 1-2; n 4349 (7220), 18-2-1909, p. 1, cols. 3-4; n 4351 (7222), 20-2-1909, p. 1, cols. 1-2; no 4357 (7228), 27-2-1909, p. 1, cols. 1-2; no 4362 (7233), 4-3-1909, p. 1, cols. 1-2 e no 4365 (7236), 7-3-1909, p. 1, cols. 3-4.

(53) Por exemplo, Adelaide Cabete, iniciada em 1907 na loja Humanidade, tal como Maria Veleda e Ana de Castro Osório. Cf. A. H. de Oliveira Marques, Dicionário da Maçonaria Portuguesa, vol. I, Lisboa, Editorial Delta, 1986, c. 226 e vol. II, cls. 1474 e pp. 1065-1066 e Fernando Marques da Costa, A Maçonaria Feminina, Lisboa, Vega, s.d.

(54) Apud Maria Helena Vilas Boas e Alvim, "Angelina Vidal. Uma vida ao serviço da propagação da nova ideia", Revista de Ciências Históricas, vol. VIII, 1993, p. 169. 
que a melhoria das condições económicas que dignificassem a maternidade devia ter precedência sobre o direito de participação política. A superação da precariedade laboral advinha, em primeiro lugar, da tomada de iniciativas por parte da mulher que mitigassem a sua débil situação, tal como o associativismo, a criação de caixas económicas e a maternidade. Para alertar sobre estas questões, Angelina Vidal e Maria Veleda proferiram diversas conferências femininas.

Se o trabalho regeneraria a mulher, a sua emancipação decorreria, essencialmente, da educação ${ }^{(55)}$. Na esteira de Stuart Mill e Novicow ${ }^{(56)}$, a instrução feminina, enquadrada no horizonte da democratização do ensino, era a única via para que ela se pudesse equiparar, civil e politicamente, ao homem. A educação era, na sua essência, um meio de ataque contra o poder do clericalismo. Mais do que assimilar os princípios básicos da leitura e da escrita, seria "necessária a instrução integral, enciclopédica, a instrução secundária que é a que dá noções exactas sobre todas as coisas e a que por consequência pode garantir o espírito contra a superstição"(57). Denunciando a influência particular do clero-principalmente através da confissão auricular, - e a proliferação do analfabetismo que grassava no seio das mulheres, por exemplo, Consiglieri Pedroso considerava que "os direitos políticos nas suas mãos seriam até um perigo"; e esclarecia: "a que influências obedece ainda hoje a mulher? A influências clericais. Ora, a arma dos direitos políticos nas mãos da mulher seria fatalmente um elemento de retrogradação, elemento tanto mais perigoso, quanto até a sedução do belo sexo o auxiliaria muitas vezes [...] A interferência da mulher na política é mais um elemento de perturbação e dos mais perigosos"(58). No que respeita aos direitos políticos da mulher, a posição de Fernão Botto-Machado foi a mais

(55) Cf. Idem, "Da Educação da Mulher no Portugal Oitocentista. Notas de um estudo", Revista de Ciências Históricas, vol. V, 1990, pp. 321-34.

(56) Este autor publicou a obra L'Affranchissement de la femme, Paris, Félix Alcan, Éditeur, 1903, traduzida para português, em 1910, por Agostinho Fortes, na coleç̧ão "Biblioteca d'Educação Nacional", por ele dirigida, com o título A Emancipação da Mulher, Lisboa, Typographia de Francisco Luís Gonçalves, 1910.

(57) O Século, $\mathrm{n}^{\circ} 715,9-5-1883$, p. 2, col. 4.

(58) Idem, ibidem. Idêntica foi também a posição de Trindade Coelho. Cf. Manual Político do Cidadão Portuguez, Porto, Typographia A Vapor, da Empresa Litteraria e Typographica, 1908, pp. 57-58. 
arrojada. Em conferência proferida no Grémio Civil do Monte, em 1907, aquele propagandista não só defendeu que ela devia pagar impostos, como devia poder votar ${ }^{(59)}$.

A mulher devia, assim, ser educada para se tornar educadora. Daí que a sua função social devesse ter mais a ver com a preparação para a cidadania do que com uma imediata participação activa na vida política propriamente dita. Maria Veleda dedicou mesmo uma conferência a esta questão ${ }^{(60)}$, na qual defendeu que "a mulher educadora desempenha um duplo papel de mãe e humanitarista [...] A missão da mulher como mãe é a mais responsável das missões. É ela que deve preparar para uma sociedade nova, uma geração consciente, altiva, generosa e robusta"(61). Por conseguinte, ela devia ser educada civicamente, em ordem a melhor desempenhar, junto da família, o seu papel de formadora e reprodutora de comportamentos e valores, sendo um excelente instrumento de republicanização e de preparação para a vida democrática ${ }^{(62)}$.

Por sua vez, o projecto cultural republicano apontava para a dessacralização da sociedade no seu todo, compreendendo a estrutura familiar e, em última análise, o matrimónio. O casamento devia ser um acto livre, protagonizado por pessoas livres, o que pressupunha a sua dissolubilidade. A reivindicação do divórcio ${ }^{(63)}$, precedida na década de 60 pela legalização do casamento civil voluntário ${ }^{(64)}$, visava consumar a tendência dessacralizadora da união matrimonial que então se iniciara. Logo, o fito

(59) A conferência teve como título "A Mulher e a Igreja". Cf. Vanguarda, $n^{\circ} 3759$ (6630), 6-5-1907, p. 2, col. 4.

${ }^{(60)}$ Teve o título "A mulher educadora" e decorreu no Centro Escolar Afonso Costa a 12 de Janeiro de 1908. Cf. Idem, n 3950 (6821), 13-1-1908, p. 2, col. 1.

(61) Maria Veleda, À Conquista. Discursos e conferências, Lisboa, Livraria Central de Gomes de Carvalho Editor, 1909, p. 139. O resumo da conferência foi igualmente publicado no jornal Vanguarda, $\mathrm{n}^{\circ} 3950$ (6821), 13-1-1908, p. 2, col. 1.

${ }^{(62)}$ Cf. Ana de Castro Osório, Às Mulheres Portuguesas, já cit., p. 65 e Bernardino Machado, Da Monarchia para a República, 1883-1905, Coimbra, Typographia de França Amado, 1905, pp. 214-258.

${ }^{(63)}$ Cf. Rui Cascão, "A família e o divórcio na Primeira República", A Mulher na Sociedade Portuguesa, já cit., vol. I, pp. 153-169 e Fernando Catroga, A Militância Laica e a Descristianização da Morte, já cit., vol. I, pp. 354-368.

(64) Cf. Samuel Rodrigues, A Polémica sobre o Casamento Civil (1865-1867), Lisboa, I.N.I.C., 1987. 
que presidiu à apologia do divórcio, foi, sobretudo, tornar o matrimónio um acto desprovido de qualquer índole sagrada ou religiosa. Neste sentido, a defesa da solubilidade do casamento foi uma das reivindicações marcantes do livre-pensamento ${ }^{(65)}$. A encabeçar a campanha pró-divórcio estiveram mulheres como Maria Veleda, Angelina Vidal e Ana de Castro Osório.

Ao enfocarmos este leque de vertentes que deram corpo à questão feminina, poderá surpreender a não inclusão da problemática do sufragismo. Porém, a verdade é que, estando a nossa base de trabalho limitada às conferências proferidas nos centros democráticos, antes da República, não encontrámos referências a este assunto, exceptuando a de Fernão Botto-Machado, já mencionada.

\subsection{A questão da educą̧ão e do ensino}

Como reconhecia Ladislau Piçarra, "a democracia pura tem por base a educação do povo"(66). O Estado democrático - porque erguido, teoricamente, a partir da universalização do sufrágio - radicava na instrução e ilustração popular. É que "l'idée que le suffrage universel n'etant pas un droit, l'électorat, comme toute autre charge politique, est une fonction, qui suppose donc une éducation"(67).

No decurso do período da propaganda republicana, nomeadamente nas derradeiras três décadas da Monarquia, a questão da educação e do ensino, entendida aqui numa dimensão abrangente, foi uma das problemáticas mais abordadas nas conferências. É evidente o surto de prelecções dedicadas à temática, principalmente a partir de 1907. No total contabilizámos 168 conferências (10\%). No entanto, não englobámos as

(65) No I Congresso do Livre-Pensamento, realizado em Abril de 1908, uma das teses discutidas relacionava-se com "As Instituições Familiares", cuja alínea a) consignava "o estabelecimento da lei do divórcio" e concluía que "o divórcio tal como está estabelecido na lei francesa impõe-se, sendo a indissolubilidade do matrimónio um atentado à liberdade e à dignidade tanto do homem como da mulher" (Vanguarda, n 4048 (6919), 22-4-1908, p. 1, col. 6).

(66) A Lucta, $\mathrm{n}^{\circ} 1423,4-12-1909$, p. 1, col. 1.

(67) Claude Nicolet, L'Idée Republicaine en France. Essai d'Histoire Critique, Paris, Éditions Gallimard, 1982, p. 242. 
respeitantes à divulgação da ciência e de conhecimentos históricos, não obstante estas aç̧ões apontarem para o mesmo objectivo paidético.

Evolução do $\mathbf{n}^{\circ}$ de conferências dedicadas à Questão do Ensino (1880-1910)

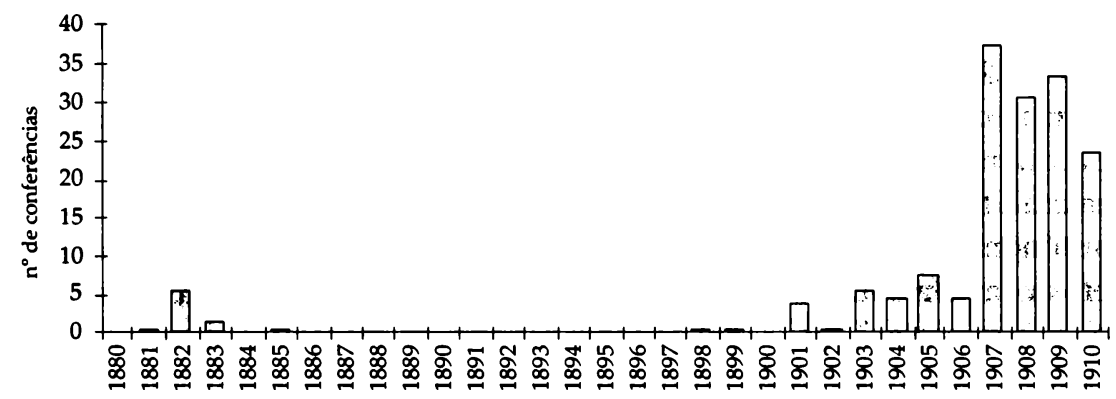

Registe-se que o alcance do valor da educação no discurso republicano traduz a influência de duas correntes filosóficas: a iluminista e a positivista. Com a primeira, tal como anteriormente aconteceu com o romantismo cultivado pelos liberais, reactualizava-se a crença optimista na educação como principal factor de progresso civilizacional, de socialização, de emancipação e perfectibilidade humana. Como fiéis discípulos de Condorcet, "les républicains [...] et leurs journaux [...] voient dans la réforme scolaire la promesse d'un progrés indéfini et affectent de conffondre la cause de la démocratie politique et de la démocratie sociale"(68). Com a segunda, reafirmava-se que a arte de educar constituía um excelente instrumento para moldar a índole de cada indivíduo, de acordo com a marcha progressiva da raça e da humanidade. A natureza seria, deste modo, enformada pela cultura e adaptada aos interesses colectivos. No fundo, pretendia-se alcançar uma verdadeira unidade espiritual, assente no primado da ciência, que deveria ser edificada não só pela escola mas também por outras práticas educativas.

O credo na inelutável emergência republicana, escorado na formação de uma nova opinião pública e de uma nova espiritualidade, tornava a

(68) Mona Ozouf, L'École, l'Église et la République, Paris, Armand Colin, 1963, p. 84 . 
educação prioritária Consequentemente, mesmo durante a fase de propaganda, o investimento educativo não se circunscreveu a uma figura de retórica, mas concretizou-se, institucionalmente, por meio de escolas ou de outros organismos com idênticas funções.

Educar significava talhar os indivíduos para a cidadania e preparar para a liberdade, ou seja, emancipar, o que conduziria à regeneração do povo e da pátria. Um cidadão instruído tinha a consciência do seu dever cívico e da importância da sua cooperação nos destinos da vida colectiva, porquanto "les bons lecteurs feront les bons électeurs"(69). A escolha livre, raiz do futuro regime republicano, só poderia ser feita por um cidadão autónomo e racional, isento da influência religiosa. Em suma, a educação era encarada como um instrumento fundamental, que ensinava a votar e a "bem votar", pelo que "l'école a toujours été placée au centre de l'ideologie républicaine comme le moyen essentiel sinon exclusif de son triomphe. Elle devait apporter la Raison, les Lumières et la Science. Montesquieu affirmait dejá que 'c'est dans le gouvernement républicain que l'on a besoin de toute la puissance de l'éducation'"(70). E só por meio da democratização do saber se poderia atingir a democratização social.

A concepção republicana encerrava uma dificuldade, a saber: como conciliar o desenvolvimento da livre escolha e da autonomia, essencial à sociedade plenamente democrática, com a necessidade fundamental de unificar, espiritual e moralmente, os cidadãos em torno dos mesmos valores? ${ }^{(71)}$ Como educar, então, para o individualismo, empregando, porém, estratégias unificadoras, a fim de se construir o que René Rémond denominou por "alma comum"(72)? A verdade-como já se provou num

(69) Idem, ibidem, p. 111.

(70) Nicolas Tenzer, Que Sais Je? La République, Paris, P.U.F., 1993, p. 81.

(71) Joaquim António Pintassilgo sistematiza a moral republicana nos seguintes valores: liberdade, igualdade, fraternidade, cooperação, filantropia, generosidade social, auxílio mútuo, solidariedade, altruísmo, valorização da família, valorização da pátria, certo puritanismo, sentido do dever, generosidade, dignidade, prudência, rectidão, previdência, espírito de iniciativa, capacidade de decisão, temperança, pundonor, fidelidade, afectuosidade, caridade, dedicação, modéstia, obediência, simpatia, coragem e energia (J. A. Pintassilgo, A Educação Cívica nas Escolas Primárias da $1^{a}$ República portuguesa (1910-1926), 2 vols., Salamanca, Trabalho policopiado, 1996, p. 194).

(72) René Rémond, L'Anticléricalisme en France de 1815 à nos jours, Paris, Fayard, 1976, p. 188. 
estudo dedicado ao fenómeno educativo na $1^{\text {a }}$ República ${ }^{(73)}$ - é que a sua escola foi, sobretudo, culturizadora e reprodutora da axiologia republicana. Desde a formação dos primeiros institutos educativos republicanos, antes da queda da Monarquia, se vinha desenhando os contornos de uma educação colocada ao serviço da nova ordem política, que se pretendia instalar. É que, sendo a República um regime edificado com base na ideologia, a educação adquiria um papel fulcral, a par do culto da pátria, como unificadora e geradora de consenso. Daí a reivindicação da escola gratuita, obrigatória e laica.

A questão do ensino foi ainda equacionada numa perspectiva bidimensional, associando, ainda que em termos diferenciados, a educação e a instrução. Ambas concorriam para o complexo processo de formação para a cidadania. De forma lapidar, Augusto José Vieira, em conferência intitulada "Educação Laica", proferida a 20 de Março de 1908, no âmbito do Congresso Nacional de Livre-Pensamento, qualificava a educação como "meio para formar corações aptos para a prática do bem", e a instrução, como a "aquisição de conhecimentos úteis aos homens que os habilitem para a luta da vida"(74). Eivado do influxo do darwinismo social, o posicionamento do livre-pensador traduz a posição consensual dos republicanos quanto à função educativa e instrutiva na construção do Estado democrático.

O conceito de educação do republicanismo pretendia reactualizar a matriz globalizante da paideia grega, equivalendo "ao conjunto de regras e preceitos tendentes a bem desenvolver e aperfeiçoar o físico, o intelectual, o cívico e o moral de uma criança"(75). Educar era, assim, um caminho de elevação do corpo, da razão e da alma. Numa perspectiva mais restrita, a educação correspondia, exclusivamente, à preparação para a cidadania, pois tinha "por fim formar o cidadão, ensinando-o a conhecer as instituições do seu país e ministrando-lhes regras de conduta, firmes e seguras, que o dirijam na vida pública"(76). Com a implantação da República, a educação cívica substituiria a educação católica, veiculando uma moral científica, sem Deus.

(73) Referimo-nos ao estudo já citado de Joaquim António de Sousa Pintassilgo.

(74) Vanguarda, $\mathrm{n}^{\circ} 4018$ (6889), 22-3-1908, p. 2, col. 2.

(75) Luís Norberto de Sousa d'Almeida Reis, A Educação Física desde o nascimento até à virilidade. These inaugural apresentada e sustentada perante a Escola Medico-Cirurgica de Lisboa, Lisboa, A Liberal - Officina Typographica, 1898, p. 12.

(76) Trindade Coelho, ob. cit., p. 3. 
À imagem do Estado democrático, que se pretendia edificar, a escola devia ser laica, gratuita e obrigatória. O ensino laico, inspirado no modelo da III República francesa, conduziria à total liberdade de consciência e à vitória da ciência sobre a religião, uma vez que "só a laicidade possibilitaria que a escola desempenhasse simultaneamente uma função consensual e integradora, isto é, fosse o lugar por excelência de sociabilização política do Estado"(77). Como Maria Veleda propagandeava, o valor da escola laica implicava "a inteira incompatibilidade com tudo quanto diga respeito à religião, por forma a deixar ao professor um campo inteiramente neutro, sem lisonjear nem agredir a educação que a criança recebe em casa [... $]^{\prime \prime(78)}$. A laicidade, para ser eficiente e produzir os seus efeitos, teria de ser integral, pelo que devia envolver professores, programas e valores.

Pela análise da temática das conferências democráticas dedicadas à questão do ensino podemos concluir que a reivindicação da laicidade só se evidenciou em meados da década de 80 do século XIX, o que se explica pelo impacto, à época, da obra escolar da III República e pelo avigoramento da campanha anticlerical em Portugal.

Ao subtrair a criança do ensino religioso e "jesuítico", a escola republicana devia converter-se num espaço aconfessional, mas comprometido e sobredeterminado pela política do Estado. Dito de outro modo, ela pautar-se-ia pela indiferença religiosa, mas não pela neutralidade axiológia, que podemos denominar "religião política". E os doutrinadores não duvidavam da facilidade de compreensão e interiorização da moral social republicana, uma vez que, inspirarada no estudo da natureza, ela seria tão convincente como as leis científicas em que se inspiraria.

Ainda que não constitua um caso isolado - passível de demonstrar o peso da solidariedade na educação cívica republicana dirigida às crianças - , tomámos como exemplo concreto deste projecto educativo os estatutos da Associação Infantil do Grémio Republicano de Alcântara (1909). Desta agremiação faziam parte alunos de ambos os sexos. Com a sua formação, procurava-se incitar, desde a idade escolar, à organização associativa, salientando-a como célula organizativa básica da sociedade. Entre os fins da associação infantil em apreço, pretendia-se: "a) desenvolver entre os associados o gosto pelo estudo e pelo trabalho; b) auxiliá-los

(77) Fernando Catroga, O Republicanismo em Portugal, já cit., vol. II, p. 387.

(78) Maria Veleda, ob. cit., p. 42. 
durante a doença; c) manter uma aula de ginástica; d) fazer propaganda de proteç̧ão às árvores e aos animais úteis ao homem e destruição dos nocivos sem tortura; e) promover excursões escolares e visitas de estudo"(79). Tais objectivos consubstanciavam a pluridimensionalidade da educação cívica republicana e espelhavam, num espaço colectivo reduzido, as linhas isotópicas da moral social que propugnava. Neles transparece a preocupação em incutir o gosto pelo trabalho, praticar a solidariedade e respeitar a natureza. Quem não demonstrasse "pelo exemplo a todas as crianças que não devem escarnecer nos velhos, destruir os ninhos, maltratar as árvores e os animais e arremessar pedras ou qualquer outro objecto que possa molestar ou causar prejuízos materiais" ${ }^{\prime(80)}$ seria punido com multa. De forma pedagógica e simples, intentava-se iniciar as crianças no comprometimento com a colectividade, ainda que de pequena dimensão, e socializar-lhes o respeito pelos outros, exercitando o altruísmo ${ }^{(81)}$.

Prezar os direitos dos semelhantes era também preservar a natureza em harmonia com o espírito da escola laica: "ensinar às crianças as verdades positivas da ciência [...] e incutir-lhes o espírito do amor, do bem e da justiça. Ensinar-lhes a amar a natureza como suprema criadora" ${ }^{\prime(82)}$. E a admiração pela natureza como condicionadora do homem - atitude bem ao gosto da pedagogia spenceriana - era ainda alimentada pela realização de visitas de estudoe pic-nics ao campo ${ }^{(83)} \mathbf{e}$ pelo culto cívico da árvore.

Mais do que uma simples transmissão de princípios morais, a escola e as agremiações infantis republicanas pretenderam a sua vivificação,

(79) A Lucta, n 1401, 12-11-1909, p. 2, cols. 7-8.

(80) Ibidem.

(81) A obra de Ana de Castro Osório, A Minha Pátria (Setúbal, Livraria Editora "Para as crianças", 1906), em especial no capítulo "A obra das crianças", reproduz pedagogicamente o incitamento à realização, pelas crianças, de obras de solidariedade e de fraternidade. col. 1.

${ }^{(82)}$ Maria Veleda, “Missão Escolar", Vanguarda, n 4434 (7304), 16-5-1909, p. 1,

(83) A título de exemplo: 60 alunos do Centro Escolar "A Lucta", de Queluz, realizaram um pic-nic, na Quinta da Fonteneira, durante o qual a professora deu uma lição de botânica. A concluir houve lanche e recreio. Cf. A Lucta, 1578, 11-5-1910 , p. 2, col. 7. 
para que fossem assimilados não apenas pela razão, mas, sobretudo, pelo coração, pelo sentimento e pelas emoções. É que a interiorização afectiva dos valores da moral social enraizava-os, profundamente, no indivíduo, aliando o seu destino ao telos colectivo da nação e da humanidade. Por isso, a sua pedagogia devia ser dirigida às capacidades cognitivas, intelectuais e, principalmente, às faculdades afectivas. A educação não se reduzia "à consciência [...], mas à educação do carácter, dos sentimentos e da vontade, porque [...] se são enormes as vantagens do saber, se é em verdade valorosíssima a posse dos conhecimentos [...] para a luta épica e ingente de au jour le jour, não são menores as vantagens resultantes duma consciência bem preparada, para exercer direitos e deveres cívicos, duma vontade bem educada para lutar e triunfar em perfeita harmonia com os princípios do belo e do justo, que são afinal, os princípios da fraternidade e da solidariedade"(84). Educar era, em síntese, nas palavras de Jules Simon, "a obra por meio da qual um espírito forma outro espírito e um coração outro coração"(85).

A busca de um novo consenso fez com que este projecto educativo fosse indissociável do fomento do patriotismo. É que o patriotismo consubstanciaria a "virtude do homem que ama real e verdadeiramente o seu país" e se envolve na sua vida cívica, porque "é instruído com a noção exacta dos seus direitos e dos seus deveres e que sabe, nas doutrinas que ouvir, distinguir o verdadeiro do falso"(86). E só a República poderia dar vivência a essa moral cívica.

Se a educação democrática pressupunha a afirmação patriótica, o republicanismo tendia a perspectivar a ordem presente, que aspirava suplantar, em termos decadentistas. Invectivar a Monarquia, enfatizando a sua decadência, reforçava o carácter regenerador do ideal republicano. O porvir radioso tornava mais intolerável o presente monárquico. Na esteira do positivismo e do organicismo, a decadência do corpo social assemelhava-se à decadência patológica de um corpo biológico. Por isso, com o escopo de corrigir "a doença da sociedade", a educação, para além da reabilitação

(84) Fernão Botto-Machado, Crenças e Revoltas, já cit., p. 101.

(85) Apud Maria Veleda, "Missão Escolar", Vanguarda, n 4433 (7304), 15-5-1909 , p. 1, col. 1.

(86) Trindade Coelho, ob. cit., pp. 15-17. 
moral, cívica e intelectual, teria igualmente de conseguir a regeneração física, essencial para a elevação da raça e da nação ${ }^{(87)}$.

Em tese defendida, em 1898, na Escola Médico-Cirúrgica de Lisboa, dedicada ao tema, Luís Norberto Reis diagnosticou o estado da decadência fisiológica portuguesa nestes termos: "perpassam pelos nossos olhos uns delicados alfernins, baixos, estreitos e curvos [...], peitos deprimidos e membros delgados; ou umas espécies de vimes, chamados meninas, livres do peso dos seios, com bacias de palmo e cintura quase invisível, bustos comprimidos e costas arqueadas, e uns e outros pálidos, o olhar baço e sem energia, linfáticos e anémicos e arrastando-se mole e languidamente ao longo dos passeios. E tudo isto, sintomas tão frisantes da decadência cada vez mais pronunciada da nossa raça, mercê do álcool, da sífilis, da falsificação do meio social e dos alimentos"(88). No mesmo sentido Ramalho Ortigão apodou Portugal de "país de magrizelas, de derreados, de espinhelas caídas"(89), e de nação empobrecida pela "debilidade da raça estiolada pela falta de uma educação atlética"(90).

Em França, foi evidente e profundo o impacto nacionalista resultante da derrota na guerra Franco-Prussiana (1871). Também em Portugal a ligação entre nacionalismo e decadência da raça ganhou maior relevo na sequência do Ultimatum inglês (1890). A República francesa, visando debelar os motivos imputados pela perda do conflito (entre os quais primava a inferioridade rácica em relação aos alemães), desenvolveu um intenso programa, tendente a reforçar a disciplina, o espírito científico, a ginástica e a higiene das populações e, em particular, dos jovens ${ }^{(91)}$. Em Espanha, por sua vez, dominava a influência pedagógica krausista,

${ }^{(87)}$ Cf. Ana Leonor Pereira, "Raças e História: imagens nas décadas finais de Oitocentos", Revista de História das Ideias, vol. 14, 1992, pp. 347-364.

${ }^{(88)}$ Luís Norberto Reis, ob. cit., p. 11.

(89) Ramalho Ortigão, "A Educação Física - Os ginastas", As Farpas, vol. VIII, Lisboa, Clássica Editora, 1992, p. 229.

(90) Idem, John Bull. Depoimento de uma testemunha, Porto, Livraria Internacional de Ernesto Chardron, 1887, p. 187.

${ }^{(91)}$ Cf. Mona Ozouf, L'École, l'Église et la République, já cit., p. 15 ss. Em França, foi criada, em 1888, a Liga Nacional de Educação Física. 
que encontrou eco na influente Institución Libre de Enseñanza, norteada pela máxima latina "mente sã em corpo são"(92).

Também a demopedia nacionalista republicana, à semelhança do exemplo francês, propugnou pela moralização física e higiénica ${ }^{(93)}$. Regenerar a raça passava, inevitavelmente, pelo exercício físico. Foi com esse objectivo que $O$ Século lançou, em 1908, uma intensa propaganda sob o lema "regeneremos a raça", visando detectar e combater as causas da decadência física dos portugueses ${ }^{(94)}$. Em suma, "como a educação moral, a educação física regenera por meio dos indivíduos, as raças e as nações, mas se em relação à educação moral, o efeito da acção educativa é no indivíduo pouco sensível para só vir a acentuar-se com efeito no carácter da raça, é-o muito mais na educação física, embora os seus resultados apenas se acentuem com saliência bem definida, no robustecimento do grupo: assim, estas duas espécies de educação verdadeiras higienes da alma e do corpo - concorrem, por intermédio do indivíduo para o aperfeiçoamento da nação"(95).

As associações republicanas salientaram, através de conferências, a importância da ginástica e da higiene ${ }^{(96)}$, esta última vocacionada, essencialmente, para a classe operária ${ }^{(97)}$. Mas, mais relevante ainda,

(92) Cf. Pilar Calvo Caballero, Política, Sociedad y Cultura en el siglo XIX, Madrid, Actas Editorial, 2002, p. 114.

${ }^{193)}$ Cf. Paulo Lauret, "Gymnastica e Hygiene", O Gymnasta, no 1, 26-3-1882, p. 1, col. 1, e Ana Leonor Pereira, Darwin em Portugal (1865-1914), Coimbra, Almedina, 2001, pp. 285-312.

${ }^{(94)} \mathrm{Cf}$. Irene Maria Vaquinhas, "O conceito de 'decadência fisiológica da raça' e o desenvolvimento do desporto em Portugal (finais do século XIX/princípios do século XX)", Revista de História das Ideias, n 14, 1992, pp. 365-387.

(95) J. Augusto Coelho, "Espécies de educação e diferença entre educação e instrução", Educação Nacional, 18-1-1903, p. 114.

(96) Note-se que, tanto no programa curricular da Universidade Livre de Lisboa de 1904, como na Universidade Popular de 1907, constava o tema da Higiene (cf. Vanguarda, $\mathrm{n}^{\circ} 2794$ (5646), 15-8-1904, p. 1. cols. 4-5, e n 3710 (6571), 7-3-1907, p. 1, col. 4). A Associação de Instrução Popular, da Figueira da Foz, organizou, em 1908, uma série de prelecções sobre "Higiene" (cf. $A$ Voz da Justiça, $\mathrm{n}^{\circ} 625$, 17-11-1908, p. 2, col. 4) e o Centro Eleitoral Republicano de Santarém animou em 1908, várias conferências sobre o mesmo tema (cf. O Debate, nº 24, 14-5-1908, p. 2, col. 4 e n ${ }^{\circ} 51,14-12-1908$, p. 1, col. 3).

(97) Cf. José de Magalhães, "A educação do povo em matéria sanitária", A Lucta, $\mathrm{n}^{\circ}$ 38, 7-2-1906, p. 1, cols. 1-2, e Ladislau Piçarra, "A educação e a política", idem, $\mathrm{n}^{\circ} 41,13-2-1906, \mathrm{p} .1$, cols. 1-2. 
foi a materialização destes preceitos, através do estabelecimento de aulas de ginástica ${ }^{(98)}$ - sobretudo sueca pelo método de Ling ${ }^{(99)}$ - e pela institucionalização de práticas higienistas (banhos ${ }^{(100)}$, vacinas e passeios ${ }^{(101)}$ ) nas crianças. Podemos referir, como exemplo, os alunos da já citada Associação Infantil do Grémio Republicano de Alcântara, que ficavam sujeitos a multas de 5 réis, revertendo estas a favor do cofre comum, "por transgressões de preceitos higiénicos tais como escarrar no chão, entornar tinta, ter as unhas sujas, não estar bem lavado, não cuidar dos cabelos, dos dentes, etc." ${ }^{\prime(102)}$. Interessava, assim, a popularização de uma moral higienista, embora a temática da higiene fosse abordada numa perspectiva multímoda ${ }^{(103)}$ : higiene das grávidas, das mães, das crianças, da habitação, da alimentação e higiene mental.

(98) Para demonstrar a importância do desporto, a Tuna Democrática Portuguesa organizou um sarau com exibições de trapézio à Leotard, argolas, esgrima, assalto à espada francesa e forças combinadas (cf. Vanguarda, n 4507 (7378), 28-7-1909, p. 3, col. 1), e a Sociedade Promotora de Asilos, Creches e Escolas um outro com forças combinadas e "demonstração da maneira de se defender na rua" ( $A$ Lucta, no 1712, 22-9-1910, p. 2, col. 1).

(99) Este método de ginástica, inovador para a época, consistia na realização de exercícios específicos para o desenvolvimento de cada músculo. $O$ seu grande divulgador foi Paulo Lauret, que dirigiu um importante ginásio no Porto, e a obra portuguesa de maior relevo neste domínio é o livro de João de Brito, Exercícios Elementares de Gymnastica Sueca, Lisboa, Typ. da Rua da Rosa, 1908.

${ }^{(100)}$ Por exemplo, os banhos na Trafaria, dedicados às crianças pobres, por iniciativa das juntas de paróquia republicanas da capital. Cf. [Carlos Ferrão], "Uma obra de altruísmo", História da República, Edição Comemorativa do Cinquentenário da República, Lisboa, Editorial "O Século", [1960], pp. 486-487. Também a Cantina Escolar de Alcântara, inaugurada a 25 de Julho de 1909, contava com uma grande sala de banho. Cf. Vanguarda, 4501 (7372), 22-7-1909, p. 2 , col. 2 .

(101) Em 1908, a Comissão Escolar do Centro Republicano do Socorro organizou, para as crianças, passeios higiénicos, e criou aulas de ginástica sueca. Cf. idem, $\mathrm{n}^{\circ} 4259$ (7130), 19-11-1908, p. 3, col. 6.

(102) A Lucta, $\mathrm{n}^{\circ} 1401,12-11-1909$, p. 2, col. 8.

(103) Como forma de vulgarização dos preceitos higienistas começou a ser publicada, em Agosto de 1909, a revista A Hygiene Popular, dirigida por Pedro Muralha, e que contava com a colaboração, entre outros, de Ricardo Jorge e António José de Almeida. 
A questão do higienismo extravasava o domínio privado e alastra-se à esfera pública e social. Era fundamental a higiene urbana, no espaço de trabalho, o número de horas de trabalho e o descanso semanal. $\mathrm{Na}$ base da decadência da raça, estariam causas consideradas como hereditárias, principalmente o alcoolismo, mais presente nas classes pobres ${ }^{(104)}$. Em conferência realizada a 7 de Fevereiro de 1909, no Centro Republicano da Pena, Eusébio Leão enumerou os malefícios do álcool, entre os quais "os seus efeitos perniciosos no indivíduo, na família e na sociedade" e a sua relação "relativamente à loucura, crime e à degeneração da raça" (105).

Dito isto, afigura-se-nos evidente que a paideia republicana propunha "dar às crianças uma educação total e optimista que, incidindo sobre o corpo, pela higiene e pela ginástica, e sobre a alma, pelo ensino cientificamente adequado e pela educação moral e cívica regenerasse a raça e formasse 'o carácter dando-lhes energia bastante para vencerem os factores que estavam a degenerar a raça nacional'"(106). Por isso, fortalecer o corpo pelo exercício físico e pela higiene não era apenas um acto individual; antes, constituía uma atitude cívica, patriótica e altruísta, consonante com a moral social. $\mathrm{E}$ foi esse patriotismo, ainda que inspirado no modelo francês, que presidiu à educação para-militar transmitida em algumas associações democráticas. Na verdade, muitos clubes possuíam secções desportivas, nomeadamente de tiro, ginástica e esgrima. Apresentamos apenas alguns exemplos: em 1887, a Associação União Democracia Social criou um curso especial de esgrima. O Clube José Estevão inicia, em Outubro de 1884, as aulas de tiro e de esgrima. Na redacção d'O Século, abriu, a 1 de Maio de 1885, uma sala de esgrima para sócios ${ }^{(107)}$. O Centro António José de Almeida deu início a uma aula de ginástica sueca, em Junho de 1907, e de ginástica infantil, em 1910 ${ }^{(108)}$. Um ano antes, o Grupo Tomás Cabreira iniciou aulas diurnas e nocturnas de esgrima ${ }^{(109)}$.

(104) Este assunto foi abordado em conferência a 21 de Junho de 1908, no Centro de Propaganda Liberal de Setúbal, por Belarmino de Abreu (Germinal, $\mathrm{n}^{\circ} 225$, 14-7-1908, p. 1, col. 3).

(105) Ibidem, nº 4338 (7209), 7-2-1909, p. 1, col. 4.

(106) Fernando Catroga, O Republicanismo em Portugal, já cit., vol. II, p. 445.

(107) Estas aulas foram dirigidas pelo professor Manuel Cida. Cf. O Século, $\mathrm{n}^{\circ} 1308,16-4-1885$, p. 1, col. 3.

(108) Cf. $A$ Lucta, no 1518, 11-3-1910, p. 2, col. 8.

(109) Funcionava às segundas e às sextas-feiras. Cf. ibidem, nº 1397, 8-11-1909, p. 1, cols. 7-8. 
Os dados apresentados são bem o exemplo da importância específica do tiro ${ }^{(110)}$ e da esgrima ${ }^{(111)}$. À imagem do modelo suíço, e da influência do ensino para-militar francês, ligado à criação dos batalhões escolares, os grémios democráticos fomentaram estas modalidades desportivas em prol da sua mensagem cívica e patriótica ${ }^{(112)}$. O mérito da componente desportiva nestas sociedades residia na "apprentissage de la démocratie par le travail, et l'émulation, par la mise en commun des compétences et l'exercice de la volonté individuelle, par le développement d'un caráctère sociable et le respect des exigences de la vie commune"(113).

Tal como o tiro e a esgrima, também a ginástica deve ser enquadrada no âmbito do culto e da defesa da pátria, pois não se reduzia a "uma questão de circo, nem de barraca de feira, é uma alta e grave questão de educação nacional"(114). Em causa estava a decadência da nação, resultante da degenerescência da raça. E, como conclui Paulo Lauret, grande divulgador dos exercícios gímnicos, sobretudo da ginástica sueca segundo o método de Ling, "a ginástica faz parte da educação e da política da

(110) Até à década de 70 o tiro esteve confinado aos exercícios militares. A sua divulgação nas escolas teve início quando, na sessão da Câmara Municipal de Lisboa de 12 de Julho de 1875, foi autorizado o então vereador republicano, José Elias Garcia a "regular as escolas municipais. Começou então o início do estabelecimento da ginástica e da instrução militar nas escolas sendo a primeira a Escola Municipal $n^{\circ} 1$, ao Campo de Santa Ana e mais tarde a $n^{\circ} 2$, à Rua da Boa Vista" (Boletim da União dos Atiradores Civis Portugueses, n 1, Jan. de 1908, p. 9). Foi o vereador Teófilo Ferreira, quem organizou, de facto, o primeiro batalhão escolar, tendo este feito o seu desfile inaugural a 24 de Agosto de 1882. Por decreto governamental de 1892 esse ensino foi extinto. Em França, com a criação, em 1882, dos batalhões escolares, são organizadas sociedades de tiro e de ginástica. Cf. Ronald Hubscher (dir.), L'Histoire en Movements. Le sport dans la société française (XIXe-XXe siècles), Paris, Armand Colin, 1992, pp. 17-56.

(111) Sobre a importância da esgrima veja-se Sousa Viterbo, A Esgrima em Portugal. Subsídios para a sua História, Lisboa, Manuel Gomes Editor, 1896.

(112) "Le tir fédéral suisse, c'était le symbole du patriotisme de tout un pays. En France, il devint celui des republicains" (Jean-Gabriel Ravey, "Les sociétés republicaines (tir, gimnastique et musique) du Département de Doubs et leurs relations avec la Suisse, de 1870 à la fin du siècle", Histoire et Société Contemporaines. Sociétés et Sociabilité au XIXe siècle. Colloque à l'Université de Lausanne, tomo 5, 1986, p. 81).

(113) Idem, ibidem, p. 85.

(114) Ramalho Ortigão, As Farpas, já cit., vol. VIII, p. 230. 
higiene e da terapêutica"(115). Os exercícios gímnicos agiam de forma a disciplinar o corpo e a integrá-lo no corpo colectivo, como se de uma metáfora da sociedade se tratasse. O movimento republicano, em harmonia com as descobertas e inovações científicas no campo da biologia e da medicina, e interessado no vigor da raça lusa, envolveu-se, através dos seus centros, na divulgação das novas ideias sobre o higienismo ${ }^{(116)}$.

Mas o Centro Republicano da Pena foi mais longe. Por iniciativa do médico Brito Camacho, em conjunto com Augusto de Vasconcelos e Afonso de Lemos, a 22 de Março de 1907 abriu um posto de vacinação gratuito, ao qual podiam aceder todos os interessados ${ }^{(117)}$. Por seu turno, o Centro Escolar "A Luta", de Queluz, ofereceu, em 1909, aos seus 50 alunos assistência médica gratuita, ministrada pelo Dr. Ponte e Sousa ${ }^{(118)}$. Em 1910, o Centro Henriques Nogueira vacinou todas as crianças da sua escola ${ }^{(119)}$, assim como os alunos dos Centros de Santos e António José de Almeida foram vacinados contra a varíola ${ }^{(120)}$.

Subjacente aos diversos e complementares domínios da educação republicana, assim como às estratégias que nortearam a sua divulgação e inoculação, já estava a intenção de se "fabricar cidadãos". António Moura, no jornal $A$ Verdade, de Tábua, criticava a atitude "enformadora" dos centros antidinásticos: "os republicanos não ensinam os filhos do povo, para darem luz aos pequeninos cérebros em trevas. [...] Eles ensinam os filhos do povo, mas é com a condição, é com a mira de fazer deles republicanos, e de fabricarem de antemão essa carneirada cega e obediente, que poderá ser tudo, menos eleitores de um país livre. Ensinam-nos nas

(115) Paulo Laudet, "Utilidade dos exercicios do corpo", O Gymnasta, n 7, 306-1882, p. 1, col. 2. Cf. António Gomes Ferreira, "A acção de Paulo Lauret na promoção da educação física no Porto nos finais do século XIX", Ensaios em Homenagem a Joaquim Ferreira Gomes, Coimbra, Núcleo de Análise e Intervenção Educacional da Faculdade de Psicologia e Ciências da Educação da Universidade de Coimbra, 1998, pp. 299-306.

(116) Cf. Ana Leonor Pereira e João Rui Pita, "Liturgia higienista no século XIX. Pistas para um estudo", Revista de História das Ideias, vol. 15, 1993, pp. 437-559.

(117) Cf. Vanguarda, 3727 (6588), 24-3-1907, p. 1, col. 4.

(118) Cf. Ibidem, $\mathrm{n}^{\circ} 4520$ (7391), 10-8-1909, p. 1, col. 5.

(119) Cf. A Lucta, no 1668, 9-8-1910, p. 2, col. 5.

${ }^{(120)}$ Cf. Ibidem, $\mathrm{n}^{\circ} 1673,14-8-1910$, p. 2, col. 3. 
escolas dos centros, mas pedem-lhes em paga, de que, quando forem homens, lhes dêem votos!"(121).

De facto, o investimento republicano na educação da infância era movido pela expectativa de enformar os futuros cidadãos, sob o signo da infalibilidade da ciência e da crença optimista na capacidade perfectibilizadora do homem. Sendo assim, o seu pensamento pedagógico privilegiava o ensino infantil em duas vertentes: a educação "préprimária" e primária ${ }^{(122)}$. No âmbito da educação das crianças dos 3 aos 7 anos de idade, o movimento encetou importantes esforços no sentido da introdução do "ensino maternal"(123). Em 1907, inicia-se uma campanha de angariação de fundos e de divulgação das finalidades da Escola Maternal, através de conferências e publicações ${ }^{(124)}$.

Segundo Borges Grainha, era preciso reconstruir uma pátria nova: "Como? formando uma nova geração: indo quase buscá-la ao berço, para que venha pura". E aquele tipo de ideação constituía uma espécie de prolongamento da "'maternidade biológica' numa forma superior de maternidade, a sociológica"; e concluía: "é bom portanto que se saiba que nos jardins de infância as crianças são as plantas e o professor o jardineiro" ${ }^{\prime 125)}$. Concomitantemente, a educação maternal das crianças que propugnavam serviria, ainda, para as "arrancar da nebulosa do

${ }^{(121)}$ António Moura, "Os políticos da minha terra", A Verdade, n 6, 9-9-1909, p. 1, col. 4 .

(122) Cf. Newton de Macedo, "Cultura e Assistência", História de Portugal, Damião Peres (dir.), vol. VII, Barcelos, Portucalense Editora, 1935, pp. 675-678.

${ }^{(123)} \mathrm{A}$ ideia das Escolas Maternais terá partido do anarquista Campos Lima que, em 1906, fundou a Escola Livre, em Coimbra, inspirada na comuna escolar "La Ruche" de Rambouillet (Paris). Esta iniciativa foi seguida por Ilda Jorge e por um grupo de professoras, que projectaram a instalação da Escola Maternal para crianças dos 3 aos 7 anos, segundo o método de Fröebel. Cf. Edgar Rodrigues, Breve História do Pensamento e das Lutas Sociais em Portugal, Lisboa, Assírio \& Alvim, 1977, pp. 113-114.

(124) Um exemplo dessas publicações foi o Jornal dos Pequenitos, dirigido por Ana de Castro Osório, dado à estampa em 1907.

(125) Palavras de Borges Grainha proferidas em conferência feita na Sociedade de Geografia, a 13 de Abril de 1907, sob o título "Escolas Maternais e Jardins de Infância". (Cf. Vanguarda, nº 3737 (6008), 14-4-1907, p. 3, cols. 3-4). 
Cristianismo e prepará-las para o amor e justiça que constituem a Humanidade"(126).

Nas palavras de Borges Grainha ressoa a influência do projecto froebeliano do Kindergarthen ${ }^{(127)}$. O princípio dos jardins de infância, segundo Fröebel ${ }^{(128)}$, consistia no pleno convívio das crianças com a natureza. Deste modo, contactariam com uma obra magnificente e aprenderiam a cuidar de si próprias, cuidando das plantas. É certo que a capitalização republicana do projecto do pedagogo alemão (já anteriormente defendido por Rodrigo de Freitas) só poderia ser alcançada mediante a secularização da escola. Porém, o conceito básico dos jardins de infância compaginava-se com o discurso pedagógico do movimento: comungar com a natureza, desenvolver as capacidades de aprendizagem prática e intuitiva (método concêntrico, que consiste no gradual e paulatino aprofundamento do conhecimento a partir do mais simples para o mais complexo), em oposição ao método teórico de memorização do ensino "jesuítico", vivificar a fraternidade, o altruísmo, adquirir hábitos de trabalho, e adestrar as habilidades manuais. Em conclusão, a escola maternal desempenharia "a dupla missão educativa e de solidariedade prática"(129).

$\mathrm{Na}$ arquitectura deste projecto escolar, os jardins de infância e o ensino "pré-primário" situavam-se na fase preparatória do ensino primário. O analfabetismo em Portugal - que, em 1900, rondaria os $80 \%$ - era, indubitavelmente, a grande mal que urgia ser expurgado ${ }^{(130)}$. Neste ponto

(126) Manuel de Arriaga, em conferência pronunciada na Sociedade de Geografia em 10 de Maio de 1907, sob o título "Escola Maternal". Cf. Idem, $\mathrm{n}^{\circ} 3764$ (6635), 11-5-1907, p. 1, col. 6.

(127) Cf. Ladislau Piçarra, "Jardins de Crianças", A Lucta, $\mathrm{n}^{\circ}$ 1559, 22-4-1910, p. 1, cols. 1-2, e Teófilo Ferreira, "Escolas infantis ou jardins de Fröebel. Apontamentos para a sua história em Portugal", Fröebel. Revista de Instrução Primária, $\mathrm{n}^{\circ} 1$, Abril 1882, pp. 2-3.

${ }^{(128)} \mathrm{Cf}$. Solomon Bluhm, "Fröebel, Friederich", Encyclopedia of Education, Leleyc Deighton (dir.), vol. 4, s.l., Cromwell-Collier Educational Corporation, 1971, pp. 98-105. Em Portugal, o prestígio do pedagogo alemão ficou marcado desde 1882, altura em que foi comemorado o seu centenário. Cf. O Século, n ${ }^{\circ} 391,21-4-$ -1882 , p. 3, col. 3 .

(129) Maria Veleda, À Conquista, já cit., p. 70.

(130) Com o fito de combater o analfabetismo foi criada a Liga Nacional de Instrução, em 1907, cujo modelo se inspirou na Ligue d'Enseignement, fundada por Jean Macé. A Liga, presidida por Consiglieri Pedroso, consignava como seu 
de vista, os republicanos davam continuidade à perspectiva liberal e romântica ${ }^{(131)}$.

Para o concretizar, esforçaram-se por divulgar o método João de Deus ${ }^{(132)}$, através da Cartilha Maternal, considerada por Manuel Laranjeira como uma "forma de ensinar a ler sem violentar o espírito, nem desmoralizar a inteligência de quem aprende; de ensinar a ler facilmente, espontaneamente, naturalmente, nem enfastiando, antes deleitando o discípulo [... $]^{\prime \prime(133)}$. Em 1882, por iniciativa de Casimiro Freire e do jornal O Século, foi criada a Associação de Escolas Móveis. Esta agremiação estabeleceu missões ambulantes de alfabetização em vários pontos do país - muitas das quais funcionaram em clubes antimonárquicos-e difundiu, por meio de conferências, o método criado pelo poeta $^{(134)}$.

Como facilmente se percebe, para a prossecução do seu projecto, a demopedia republicana procurou o apoio do professorado. Significa isto que prometia aos professores um papel ideológico insubstituível. Caberlhes-ia a missão de constituírem o "sacerdócio" laico da "igreja cívica do povo" - a Escola ${ }^{(135)}$, pois deveriam ser, não só agentes veiculadores de conhecimentos, mas também mestres de moralidade cívica; o que

primeiro objectivo "acabar com o analfabetismo aviltante que nos degrada"; para isso propunha-se fazer o "cadastro do analfabetismo". Cf. "Liga Nacional de Instrução", Portugal Novo. Revista de vulgarisação scientifica, n 1, 20-4-1907, p. 15.

(131) Cf. Rui Ramos, "Culturas de alfabetização e culturas de analfabetismo em Portugal: uma introdução à história da alfabetização no Portugal contemporâneo", Análise Social, vol. XXIV, nº 103-104, 1988, p. 113 ss.

(132) Uma das grandes defensoras deste método foi Carolina Michaëlis de Vasconcelos. Cf. C. M. de Vasconcelos, "A cartilha portuguesa e em especial a do Snr. João de Deus", O Ensino. Revista do Colégio Portuense, $\mathrm{n}^{\circ} 2,16-10-1877 ; \mathrm{n}^{\circ} 3$, 1-11-1877; $n^{\circ}$ 5, 1-12-1877. Veja-se, ainda, Joaquim Ferreira Gomes, "Algumas reacções em torno da 'Cartilha Maternal' de João de Deus", Revista Portuguesa de Pedagogia, 1976, p. 40 ss. Também Manuel Laranjeira foi um grande apologista desta pedagogia. Cf. Obras de Manuel de Laranjeira, (Org., Pref. e Notas de José Carlos Seabra Pereira), vol. II, Lisboa, Edições Asa, 1993, pp. 131-228.

(133) Boletim de Propaganda da Associação de Escolas Móveis, Bibliotecas Ambulantes e Jardins-Escola, n² 2, Out.-Nov.-Dez., 1910, p. 11.

${ }^{(134)}$ Cf. O Mundo, $\mathrm{n}^{\circ} 1631,1-4-1905$, p. 2, col. 4 e Vanguarda, $\mathrm{n}^{\circ} 3954$ (6825), 17-1-1908, p. 3, col. 5 .

${ }^{(135)}$ Cf. António Nóvoa, ob. cit., vol. I, p. 492 ss. 
quer dizer que via no instrutor e na escola os sucessores (e os sucedâneos) do padre e da Igreja"(136).

\subsubsection{A ciência}

Considerando que o republicanismo foi, em última análise, um cientismo, compreende-se o seu empenho em popularizar a ciência ${ }^{(137)}$. E o esforço em vulgarização e apologética explica-se por várias razões. Por um lado, acreditava-se que o estudo das ciências levaria, paulatinamente, à unanimidade de opiniões ${ }^{(138)}$. Por outro lado, e num horizonte de profundo optimismo (histórico e científico), a ciência permitiria demonstrar as capacidades do homem para entender racionalmente $o$ mundo e de, assim, se emancipar de todas as superstições, libertando-o das concepções teológicas e metafísicas, mesmo na aclaração das grandes questões insolúveis ${ }^{(139)}$. Isto é, a ciência estaria a possibilitar que o homem associasse o seu destino ao sentido evolutivo da natureza e progressivo da humanidade.

Mas, em termos propagandísticos, a persuasão popular da força da ciência como única via de compreensão do universo e de substituição da religião tinha de basear sua vulgarização no empolamento dos seus efeitos práticos ${ }^{(140)}$, pois a população-alvo só poderia interiorizar a nova

(136) Fernando Catroga A Militância Laica e a Descristianização da Morte em Portugal, já cit., vol. I, p. 209. Veja-se para, o caso francês, Jacques Ozouf, Nous les Maîtres d'École. Autobiographies d'Instituteurs de la Belle Époque, Paris, Gallimard, 1973.

(137) Sobre a divulgação da ciência no século XIX leia-se David Knight, "La popularización de la ciencia en la Inglaterra del siglo XIX", in La Ciencia y su Publico. Perspectivas Históricas, Javier Ordoñez y Alberto Elena (comps.), Madrid, Consejo Superior de Investigaciones Cientificas, 1990, pp. 311-330.

(138) Apud Diego Nuñez Ruiz, La Mentalidad Positiva en España: desarollo y crisis, Madrid, Tucar Ediciones, 1975, p. 38.

(139) Exemplo disso foi a conferência, proferida por Augusto José Vieira no Ateneu Comercial de Lisboa, a 11 de Março de 1888, e intitulada "Fora da ciência nada existe".

${ }^{(140)}$ Sobre este assunto foi realizada uma sessão de instrução no Centro Escolar Rodrigues de Freitas, dedicada à "necessidade da vulgarização de conhecimentos científicos ao alcance de todas as inteligências", no dia 18 de Novembro de 1906. Cf. Vanguarda, $\mathrm{n}^{\circ} 3604$ (6465), 18-11-1906, p. 1, col. 5. 
cosmovisão através de demonstrações pertinentes e simples, e que trouxessem benefícios ao seu dia-a-dia. Por conseguinte, não espanta que, dado o desenvolvimento científico da época, os conhecimentos divulgados não fossem profundos e incidissem sobre os domínios em que se registaram progressos mais expressivos. Por sua vez, áreas como a astronomia ${ }^{(141)}$ e a sismologia ficaram a dever a sua divulgação a acontecimentos espectaculares, sísmicos ou cosmológicos, sentidos por muitos como sinais telúricos do fim do mundo ${ }^{(142)}$. Referimo-nos, em particular, ao terramoto de 23 de Abril de 1909, que assolou a região de Benavente e parte do Ribatejo, bem como ao aparecimento do cometa Halley, em Maio de 1910, sobre o qual foram proferidas quatro conferências $^{(143)}$. Curiosamente, o devastador sismo coincidiu com a realização do $10 .{ }^{\circ}$ Congresso Republicano, em Setúbal, e em que se optou pela via revolucionária, opção que foi aproveitada para incendiar a propaganda apocalíptica feita pelos meios clericais. Nestes casos concretos, invocavam-se os conhecimentos científicos para se desmistificar as explicações teológicas e metafísicas, em ordem a conseguir-se alargar a positificação dos espíritos. As ligações do poder da ciência à melhoria das condições de vida das populações foram igualmente relevadas em outros domínios, conforme mostra a seguinte distribuição:

${ }^{(141)}$ Dedicada à astronomia, decorreu uma conferência em Tomar, na Biblioteca Municipal, a 11 de Fevereiro de 1883, orientada por Afonso Acácio Martins Velho, sobre as "Ideias gerais de cosmogonia e astronomia popular".

(142) Cf. Fernando Catroga, "Decadência e regeneração no imaginário republicano dos finais do século XIX", in Actas do Congresso Internacional Los Ibéricos y el Mar. El Estado y la Política, vol. 3, Salamanca-Madrid, Sociedad Estatal Lisboa'98, 1998, pp. 432-435.

(143) Uma conferência foi proferida por Inocêncio Camacho, a 14 de Maio, na Caixa Económica Operária. As três restantes, tiveram como autor Duarte Leite e trealizaram-se no Porto, (no Teatro Águia de Ouro), a 13 de Maio e no Centro Lordelo do Ouro, a 13 e 14 de Maio. 


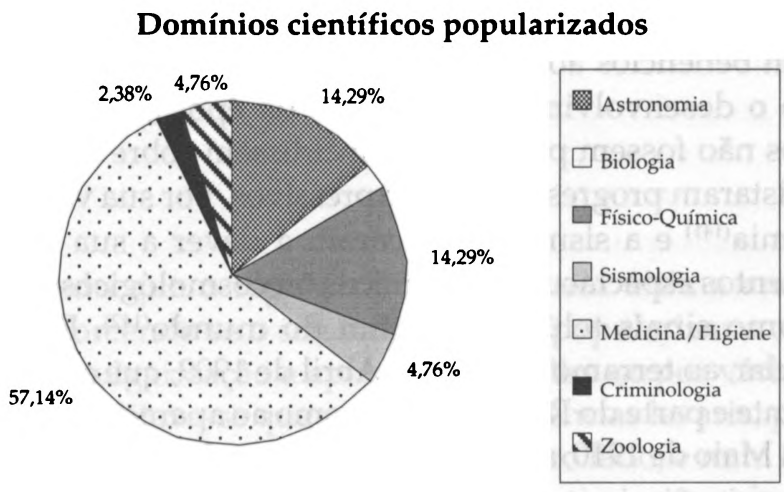

De facto, das 76 conferências $(4,5 \%)$ proferidas sobre a temática científica, mais de metade versou sobre questões ligados à medicina e à higiene. Elas incidiram sobre diversos aspectos da vida individual e colectiva, abordando problemas como a assepsia no vestuário, no corpo, na alimentação, na habitação, no trabalho e na escola; trataram, igualmente, da higiene das grávidas, das crianças (pela difusão da puericultura), e do método higiénico de pasteurização do leite. Por sua vez, associaram a higiene mental ao problema do álcool e à criminologia, e alertaram para a importância da vacinação, sobretudo das crianças.

O esforço de popularização da higiene visava, como sublinhámos na abordagem da problemática do ensino, superar a decadência fisiológica da raça portuguesa, de modo a regenerá-la. Mas também reflecte a consciência da importância da higiene para a saúde, individual e social, na sequência dos avanços da bacteriologia e microbiologia. Com efeito, os progressos coevos na área biomédica incidiram, principalmente, sobre a compreensão dos mecanismos de contágio das doenças e dos seus agentes patogénicos, suscitando a emergência de uma nova mentalidade etiopatológica, em consequência das descobertas de Pasteur. Deste modo, a doença passou a ser vista como o resultado de uma agressão, ou como uma contaminação microbiana ou bacteriológica ${ }^{(144)}$. Ainda na área das ciências biológicas, o evolucionismo darwinista estabeleceu uma nova

(144) Cf. Ana Leonor Pereira e João Rui Pita, "Ciências", in História de Portugal, José Mattoso (dir.), vol. V- O Liberalismo, Lisboa, Círculo de Leitores, 1994, p. 662. 
abordagem do homem e da natureza que, em última análise, permitiu a justificação cientista da agregação do telos da história e da humanidade ao destino do mundo natural ${ }^{(145)}$.

No âmbito da física e da química registaram-se, igualmente, importantes descobertas com efeitos no quotidiano ou na indústria ${ }^{(146)}$. Foi no século XIX que se estabeleceram as disciplinas fundamentais da física: a mecânica, o calor ${ }^{(147)}$, a termodinâmica, a electricidade, o magnetismo, a óptica e a acústica ${ }^{(148)}$.

Destacou-se nesta popularização a Associação União Democracia Social. Em 1887, tomou várias iniciativas para divulgar as ciências físico-químicas, mormente, em áreas da física recém-descobertas (acústica ${ }^{(149)}$, produção de calor ${ }^{(150)}$, electricidade $\left.{ }^{(151)}\right)$, e procurou-se fomentar a iniciação ao método experimental. Para isso, criou-se um museu de instrumentos laboratoriais e integrou as disciplinas de física e de química no currículo da escola.

(145) Sobre o darwinismo, Miguel Bombarda proferiu uma conferência, a 5 de Julho de 1909, na Academia de Estudos Livres.

(146) Acerca deste assunto, Elias Garcia proferiu uma conferência no Clube Henriques Nogueira, a 3 de Junho de 1883, dedicada ao tema "Trabalho e a ciência".

(147) Assunto da conferência de Pedro Silva, na Associação União Democracia Social, a 13 de Agosto de 1887, intitulada "Produção do calor e sua utilidade nas aplicações da moderna indústria".

(148) Teor da conferência de Pedro Silva, na Associação União Democracia, a 17 de Agosto de 1887, intitulada "A acústica e as suas leis". Por exemplo, em 1884, José Júlio Rodrigues conferenciou sobre matérias científicas no Teatro da Trindade. A 11 de Maio falou sobre "A Química dos pobres e dos enfermos"; em 25 de Maio focou "A vida dos micróbios"; no dia 8 de Junho orou sobre "Cousas portuguesas" e a 22 de Junho aludiu ao "Universo", (cf. O Século, $\mathrm{n}^{\circ} 1022,9-5-1884$, p. 3, col. 1). No dia 6 de Junho referiu-se aos "Cinco sentidos", (cf. O Século, $\mathrm{n}^{\circ} 1072,8-7-1884$, p. 2, col. 5-7) e, a 20 de Julho, falou sobre "A cólera", (cf. O Século, n 1079, 16-7-1884, p. 2, col. 6).

(149) Cf. O Século, n 2037, 26-8-1887, p. 2, col. 4.

(150) Cf. ibidem, $\mathrm{n}^{\circ} 2023,10-8-1887$, p. 2, col. 6.

${ }^{(151)}$ Cf. ibidem, $\mathrm{n}^{\circ} 2010,26-7-1887$, p. 2, col. 6. 


\subsubsection{A história}

"De todas as ciências modernamente cultivadas, não há nenhuma que tenha o condão de atrair tanto as atenções, como a história" (152). Começava assim a primeira conferência do ciclo "As grandes épocas da história universal", proferido por Consiglieri Pedroso, na Associação dos Jornalistas (1883). Quer isto dizer que o republicanismo procurou acasalar os argumentos cientistas com os de cariz historicista, tomando posição num terreno cultivado por outras ideologias. Na verdade, a história concitou o interesse da generalidade da "inteligência" oitocentista, pois devemos ter presente que, no século XIX, se enfatizou a "sociedade-memória", em que através da historiografia e do "prestígio dos historiadores, os poderes fomentaram várias liturgias de recordação, tendo em vista socializar e enraizar a(s) nova(s) memória(s) em construção (ou em processo de refundação)" ${ }^{\prime(153)}$. No caso em apreço, também se recorria ao passado para se demonstrar por que é que a República devia ser o remate da evolução histórica, actualizando uma necessidade que já estaria em potência nos primórdios da humanidade.

A incessante presença da Clio neste tipo de discurso ficou exarada nos anais da literatura pela indelével e irónica pena de Eça de Queirós. Em $A$ Capital, o escritor relata uma passagem em que Artur, a convite de Nazareno, assiste à inauguração de um clube republicano; eis quando "um homem de idade, muito feio [...], com um caderno de papel na mão", se levantou e disse: "Eu pensei que, neste dia de inauguração, seria conveniente ler algumas páginas, que pusessem diante do espírito de todos as fases que tem atravessado a Liberdade"; e começou a ler: "se remontarmos aos tempos quase mitológicos, encontramos o primeiro mártir da liberdade, (Prometeu) pregado sobre um rochedo, e tendo o flanco devorado pelo bico de bronze de um incansável abutre... Havia em redor um vago pasmo: o que era? Examinava-se o caderno espesso, azul, cosido com guita. O quê! Ia ler aquilo tudo?"(154). Como se vê, o autor de Os Maias captou com argúcia e humor a contaminação da

(152) Consiglieri Pedroso, As Grandes Épocas da História Universal, Porto, Livraria Civilisação de Eduardo da Costa Santos-Editor, 1883, p. 12.

(153) Fernando Catroga, Memória, História e Historiografia, Coimbra, Quarteto, 2001, p. 57.

${ }^{(154)}$ Eça de Queirós, A Capital, Lisboa, Edição "Livros do Brasil”, s.d., pp. 251-252. 
retórica historicista debitado nas agremiações republicanas. Mas, como se explica o ênfase que davam à história?

Antes de mais, importa esclarecer que o lugar da divulgação de perspectivas históricas se revestiu de um cariz multímodo. Por um lado, serviu de mote a inúmeras conferências e colóquios; por outro, o historicismo constituiu uma importante fonte de argumentação sobre múltiplos assuntos divulgados. Cada temática abordada era, por norma, alvo de retrospectivas filiadoras. E, finalmente, a história continha uma evidente utilidade social, e mesmo político-ideológica, na medida em que só com a criação de novas memórias (neste caso, da memória republicana, que se pretendia confundir com a memória nacional) se poderia edificar uma entidade espiritual renovada, ou seja, uma nação verdadeiramente republicanizada.

O total de conferências relacionadas com a temática histórica foram $142(8,3 \%)$. A época que se registou maior incidência foi, como fica evidente pelo gráfico seguinte, o derradeiro lustro da Monarquia.

\section{Evolução do $\mathbf{n}^{\circ}$ de conferências sobre História}

(1880-1910)

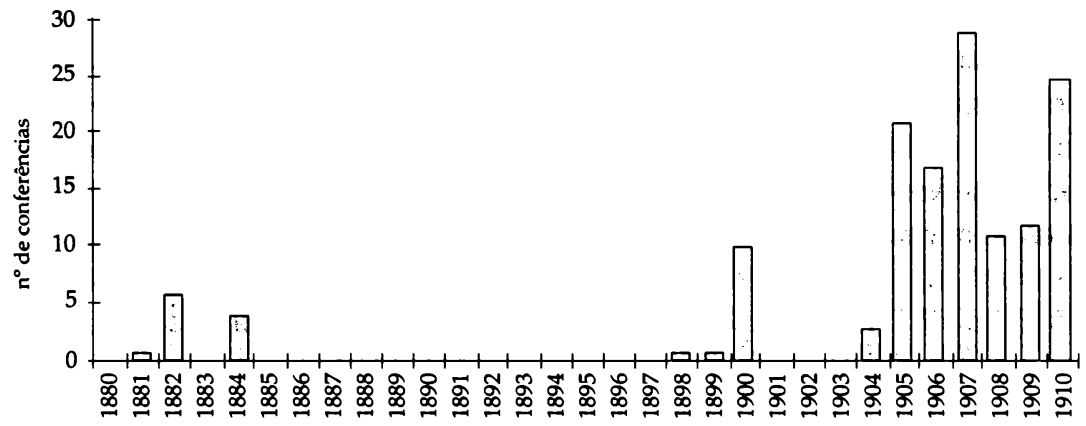

Na linha da herança iluminista, acreditava-se que o transcurso do tempo evoluía em direcção ao progresso e à perfectibilidade humana. Daí que, exemplarmente, no programa do "Curso Livre de História Universal" para o ano de 1908 (ciclo de conferências proferidas por Agostinho Fortes, na Academia de Estudos Livres) constasse, como palestra última, este tema: "A lei da perfectibilidade humana, única a que obedece a humanidade". Nessa prelecção, o conferencista estabelecia a síntese das anteriores e sublimhava o sentido que norteou o teor da 
série $^{(155)}$. Por sua vez, no plano do mesmo curso para 1909, Fortes voltava a especificar que a finalidade da divulgação histórica residia em perscrutar o passado, a fim de se comprovar a "marcha ascensional da civilização para o cosmopolitismo e para a paz"(156).

Esta perspectiva remete para uma visão linear do tempo, de raiz judaico-cristã e que, na modernidade, se concretizou como um sentido optimista de progresso ${ }^{(157)}$. E o historicismo republicano reactualizou essa visão iluminista, exemplarmente teorizadora, nos finais do século XVIII, por Condorcet, para quem "as esperanças quanto à condição futura da espécie humana [se reduziam] a estes três pontos importantes: a destruição da desigualdade entre as nações; os progressos da igualdade num mesmo povo; e, finalmente, o aperfeiçoamento real do homem" (158).

Em suma, de acordo com o historicismo perfectibilista, a gesta colectiva consistia num processo de evolução cosmopolita. Para popularizar esta convicção, realizaram-se vários ciclos de conferências dedicados à história universal ${ }^{(159)}$. Nos programas publicados, relativos a estas séries de palestras, encontra-se a intenção das prelecções: demonstrar que o progresso humano e a emergência da República (nacional e ecuménica) constituíam a consumação do telos universal. Como exemplo, recorremos ao programa genérico das "Lições de História Universal", de 1908, que agrupava as civilizações de acordo com o seu contributo para o progresso ecuménico. Atentemos à sua disposição: "Tempos pré-históricos; [...] Civilizações particularistas, o Oriente; Civilizações irradiantes, Grécia e Roma; Período de sincretismo, os tempos medievais; Civilizações cosmopolitas ou oceânicas, os tempos modernos"(160). Já o programa

(155) Vanguarda, $\mathrm{n}^{\circ} 3935$ (6806), 29-12-1907, p. 3, col. 1.

(156) Ibidem, $\mathrm{n}^{\circ} 4217$ (7088), 8-10-1908, p. 2, col. 5.

(157) Cf. Miguel Baptista Pereira, Tempo e Modernidade. Para uma leitura do discurso moderno, Coimbra, Livraria Minerva, 1990, pp. 75-88.

(158) Apud Patrick Gardiner, Teorias da História, Lisboa, Fundação Calouste Gulbenkian, 1984, p. 69.

(159) Registámos cinco ciclos sobre a história universal, organizados em Lisboa: em 1883, as "Grandes Épocas da História Universal", por Consiglieri Pedroso, na Associação dos Jornalistas; em 1900, no Círio Civil da Estrela, Heliodoro Salgado organizou o "Curso Livre de História" e em 1908, 1909 e 1910, na Academia de Estudos Livres, decorreram as "Lições de História Universal", da responsabilidade de Agostinho Fortes.

(160) Vanguarda, nº 3935 (6806), 29-12-1907, p. 3, col. 1. 
para 1909 clarificava os núcleos civilizacionais: "As civilizações isoladas, Egipto, Índia, Caldeia, Pérsia, China; Civilizações expansivas mediterrâneas, Fenícios, Gregos e Romanos; Civilizações cosmopolitas e oceânicas, Portugal, Espanha, Inglaterra, Alemanha"(161). Neste leque variado de civilizações estavam inscritos os povos de civilização (Kulturvoelker), aos quais pertenciam "as nações civilizadas, ou as raças progressivas, isto é, essa brilhante plêiade de povos que, desde a mais alta antiguidade, divididos num certo número de famílias principais, tem assinalado a sua passagem pela face da terra, por uma série de grandiosas conquistas, quer no campo prático do comércio e da indústria, quer na esfera ideal das aquisições científicas, das concepções religiosas ou das criações da arte"(162).

Heliodoro Salgado, no "Curso Livre de História Universal", realizado no Círio Civil da Estrela, em 1900, obedeceu a idêntica perspectiva filiadora, ao enquadrar no grupo de "civilizações isoladas: o Egipto, a Assíria, a Fenícia, a Judeia, a Índia, a Pérsia"; porém, considerava as civilizações clássicas como "civilizações cosmopolitas"(163); depois, a visão do livre-pensador seguia uma sucessão que apontava para o advento inevitável da República, como se depreende do núcleo restante do programa: "Cristianismo; Idade Média; As Descobertas; A Renascença, A Reforma, As descobertas científicas do século XVII; A filosofia do século XVIII e a Revolução; O século XIX: sua obra, suas contradições, suas tendências; A monarquia portuguesa"(164).

Note-se, todavia, que este ângulo de abordagem não subsumia as especificidades nacionais e locais, apesar da obediência ao princípio totalizante do progresso. E, tal como no domínio da sociologia, também na história a influência biologista se fazia sentir. Por conseguinte, sublinhava-se a influência do meio, ou seja, das condições mesológicas, como factores condicionadores e modificadores do homem ${ }^{(165)}$. A esta perspectiva não terá sido alheio o eco do pensamento de Taine e da sua tríade de condicionantes. As características de qualquer indivíduo ou

(161) Ibidem, n 4217 (7088), 8-10-1908, p. 2, col. 5.

(162) Consiglieri Pedroso, ob. cit., pp. 33-34.

(163) Vanguarda, nº 1139 (3085), 8-1-1900, p. 1, col. 5.

(164) Ibidem.

${ }^{(165)}$ Cf. Teófilo Braga, O Povo Portuguez nos seus Costumes, Crenças e Tradições, 2 vols., Lisboa, Livraria Ferreira-Editora, 1885. 
povo deviam-se aos factores da "raça", "meio" e "momento". Eça de Queirós, na conferência "A literatura nova (O Realismo como nova expressão da arte)" (integrada nas Conferências do Casino de 1871), subdividira-as em causas permanentes e causas acidentais ou históricas. "As causas permanentes são as que residem no solo, no clima, na raça; as acidentais provêm duma certa ordem de ideias que formam os diversos períodos históricos e determinam os costumes"(166).

A esta temática dedicou Agostinho Fortes uma conferência do "Curso de História Universal", proferida em 1909 e intitulada "Factores dos fenómenos históricos: raça, clima, meio, etc."(167). De igual modo, Consiglieri Pedroso aduziu ao estudo histórico das sociedades "as descobertas da mesologia"; que consideraram "o homem, considerado como ser social, a unidade elementar da história", relacionado-o "pela sua natureza animal com as várias ciências biológicas", pois, "como indivíduo", este estaria "sujeito a diversos estímulos do mundo físico"(168). Esta posição foi corroborada por Agostinho Fortes, quando, em conferência proferida na Associação de Classe dos Caixeiros de Lisboa, esclareceu que "o conhecimento histórico de um povo importa essencialmente para a determinação do modo de ser nacional, tanto quanto possível em fenómenos sociais, da marcha das nacionalidades"(169). Como conclui Fernando Catroga, a crença na acção do meio (físico e social) sobre os povos "implicava a necessidade de estudar as sociedades não só relevando a sua hereditariedade étnica e histórica (garantida pela linguagem e pela cultura), mas também as suas relações com o meio em que se desenvolveram (e desenvolvem), única via capaz de superar o conceito de evolução metafisicamente fundamentado (à maneira de Hegel)"(170).

(166) António Salgado Júnior, História das Conferências do Casino (1871), Lisboa, Tipografia da Cooperativa Militar, 1930, p. 51.

(167) Vanguarda, n 4217 (7088), 8-10-1908, p. 2, col. 5.

(168) Consiglieri Pedroso, ob. cit., pp. 44-45.

(169) Considerava ainda Agostinho Fortes que "para a História de Portugal devemos estudar os elementos étnicos que contribuíram para a fundação da nossa nacionalidade"; e estes terão sido, segundo o conferencista, duas tribos: os Lusones (provenientes dos Celtiberos) e os Salaicos. Cf. Vanguarda, $\mathrm{n}^{\circ} 3920$ (6791), 13-11-1907, p. 2, col. 1.

(170) Fernando Catroga, "Positivistas e Republicanos", in História da História em Portugal. Séculos XIX-XX, Luís Reis Torgal et alii (dir.), Lisboa, Círculo de Leitores, 1996, p. 94. 
Se a história universal ocupou lugar de relevo no teor desta popularização cultural, a abordagem de maior expressão incidiu sobre a história nacional. Compreende-se. Além de inscrever a República no telos cósmico, o historicismo republicano visava filiá-la na lógica do transcurso da nação. Procurava-se evidenciar que a democracia (liberdade) já estaria potenciada desde os primórdios da nação, tendo evoluído em constante conflito (drama) com a opressão (monarquia/ /igreja). A república seria o desfecho desse combate, pelo que o enaltecimento conferido a determinados factos, figuras ou períodos históricos, em detrimento de outros, acaba igualmente por espelhar essa visão finalística.

Assim, a Idade Média foi qualificada como o período áureo do municipalismo e da construção da nacionalidade, durante o qual se encetaram lutas regalistas entre os primeiros reis portugueses e "Roma e o clero". À Igreja era imputada a responsabilidade da deposição de D. Sancho II. Por seu turno, o reinado de D. Dinis foi enaltecido pelo "favor concedido à agricultura como fonte principal da riqueza pública. Fomento da Marinha e privilégios concedidos aos mareantes. Desenvolvimento literário e científico e fundação da Universidade".

A revolução de 1383-1385 foi apodada de primeiro momento de afirmação da soberania nacional. D. Fernando era visto como "um bom rei, fraco homem e desgraçado marido", vítima dos "cantos de sereia e fereza de mulher". Aquela revolta era enaltecida por ter sido a "primeira manifestação da vontade popular". A Nuno Álvares foi conferido um sentido épico pelo "grandiosíssimo feito da Batalha de Aljubarrota, cujo vencimento trouxe a consolidação da nacionalidade portuguesa". (A valorização deste facto também se reflectiu na atribuição do nome de Fernão Vasques a um clube republicano).

O período das Descobertas foi dos mais glorificados (devido ao contributo de Portugal para a modernidade e para o surgimento de uma sociedade cosmopolita. Essa também foi a época de engrandecimento nacional e de desenvolvimento científico. Porém, a perda da independência significava o terminus do expansionismo e maculava a soberania e autonomia da nação portuguesa, já infamada desde o reinado de D. João III, pela entrada da "Inquisição e do Jesuítismo". Por isso, a Restauração foi de novo elevada à categoria de momento de afirmação nacional. (Este acontecimento repercutiu-se, também, na nomenclatura dos clubes, através da criação da Associação Escolar e Eleitoral Pinto Ribeiro). 
$\mathrm{Na}$ fase subsequente ao movimento restauracionista, foi elogiada a obra reformadora do Conde Castelo Melhor e anatematizou-se o Tratado de Methuen, pelas suas "consequências desastrosas". O reinado do "rei magnânimo e fidelíssimo" era desvalorizado, pois ficou marcado pelo "amor ao divino e ao profano" de frades e feiras.

Da obra de Sebastião José de Carvalho e Melo, Marquês de Pombal, o republicanismo enalteceu a modernidade e o antijesuítismo. A celebração da expulsão da Companhia de Jesus (1759) deu origem a várias conferências dedicadas ao ministro de $\mathrm{D}$. José e, sobretudo, ao centenário pombalino. Não surpreende que, durante a década de 80 , tenha sido em 1882 que se registou um número significativo de palestras sobre a questão religiosa, muitas delas concitadas pela comemoração pombalina.

D. Maria I foi qualificada como "louca e demente", tendo estribado a sua actuação em Pina-Manique, que padecia de "liberdade-fobia". Também o reinado de D. João VI foi invectivado, assim como a "deslealdade da Inglaterra". A fase inicial do vintismo foi enaltecida, tal como o triunfo liberal na guerra civil. (O herói Gomes Freire de Andrade, mártir da liberdade, serviu também de denominação a um clube republicano; conjuntamente com António José da Silva, foram rememorados como vítimas da opressão política e clerical).

A importância dos argumentos históricos era justificada pelo seu alto valor formativo. Ao apresentar uma série de conferências sobre "História Pátria", realizadas em 1908, no Centro Republicano de Santarém, Ginestal Machado atribuiu "valor aos conhecimentos históricos como elementos de educação [...], de formação de caracteres e de benéfica influência para o conhecimento do verdadeiro patriotismo e de todos os sentimentos altruístas"(171). É que, a par dos objectivos de ordem educativa e nacionalista, eles permitiram inserir o indivíduo na diacronia da humanidade $e$ da nação, incrustando-lhe a ideia de progresso. Por outro lado, conduzia-o à apropriação de um destino colectivo, e à união consensualista dos cidadãos em torno da pátria e, em última análise, em torno da República. Uma unanimidade, aliás, que resultava claramente reforçada pelas liturgias de recordação e de socialização, ou seja, pelas práticas comemorativas ${ }^{(172)}$.

(171) O Debate, n $^{\circ}$ 50, 7-12-1908, p. 2, col. 2.

(172) Cf. Maria Isabel João, Memória e Império. Comemorações em Portugal (1880-1960), Lisboa, Fundação Calouste Gulbenkian Fundação para a Ciência e Tecnologia, 2002. 
A educação, já foi referido, era indissociável da reprodução de valores morais, muitos deles inspirados nos exemplos históricos, o que conferia à história o velho papel moralizante (e ciceriano) de "mestra da vida"(173). Assim o considerava Heliodoro Salgado na apresentação do "Curso Livre de História", realizado em 1900, no Círio Civil da Estrela, ao reconhecer que "não só vantagens intelectuais se encontram na história: há também a atender as vantagens morais. $\mathrm{O}$ estudo da história torna-nos mais doutos, mas também nos torna melhores. Dá-nos, pelo menos, as virtudes da paciência e da tolerância [...], a paciência necessária para esboçando em nossa mente uns determinados ideais podermos aguardar com toda a confiança dos crentes a hora oportuna da sua realização prática [...] e a tolerância perante opiniões divergentes da nossa" ${ }^{\prime 174)}$.

(173) Cf. Sérgio Campos Matos, Historiografia e Memória Nacional 1846-1890, Lisboa, Edições Colibri, 1998., pp. 200-206.

(174) Vanguarda, $\mathrm{n}^{\circ} 1140$ (3086), 9-1-1900, p. 2, col. 4. 


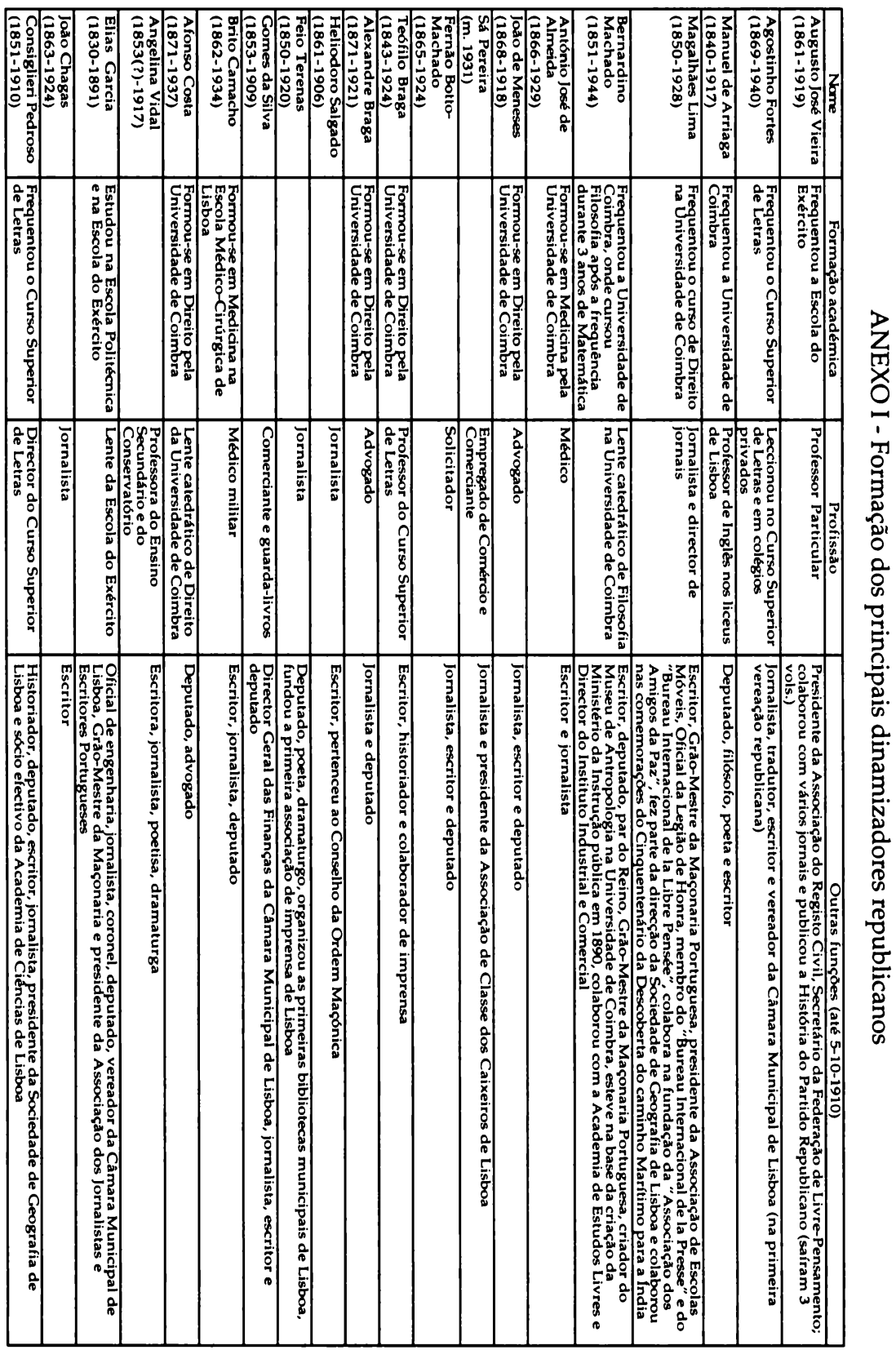


ANEXO II - Formação das principais mulheres propagandistas republicanas

\begin{tabular}{|l|l|l|}
\hline \multicolumn{1}{|c|}{ Name } & \multicolumn{1}{|c|}{ Profissão } & Outras funções (até 5-10-1910) \\
\hline $\begin{array}{l}\text { Angelina Vidal } \\
(1853(?)-1917)\end{array}$ & $\begin{array}{l}\text { Professora do Ensino Secundário e do } \\
\text { Conservatório }\end{array}$ & $\begin{array}{l}\text { Escritora, jornalista, poetisa, } \\
\text { dramaturga }\end{array}$ \\
\hline $\begin{array}{l}\text { Maria Veleda } \\
(1871-1935)\end{array}$ & Professora Primária & Escritora e jornalista \\
\hline $\begin{array}{l}\text { Ana de Castro Osório } \\
(1872-1935)\end{array}$ & Pegagoga e escritora & Jornalista e poetisa \\
\hline $\begin{array}{l}\text { Maria Clara Correia } \\
\text { Alves } \\
(1869-?)\end{array}$ & $\begin{array}{l}\text { Professora e Directora de uma Biblioteca } \\
\text { Pública }\end{array}$ & Escritora e jornalista \\
\hline
\end{tabular}

